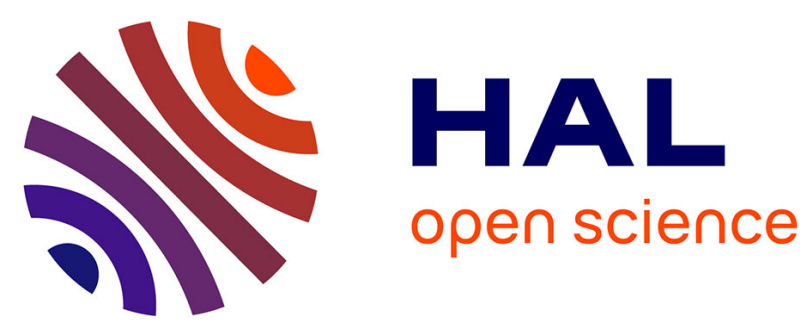

\title{
Experimental constraints on pre-eruption conditions of the 1631 Vesuvius eruption
}

\author{
Ilaria Bardeglinu, Raffaello Cioni, Bruno Scaillet
}

\section{To cite this version:}

Ilaria Bardeglinu, Raffaello Cioni, Bruno Scaillet. Experimental constraints on pre-eruption conditions of the 1631 Vesuvius eruption. Journal of Volcanology and Geothermal Research, 2020, 406, pp.107076. 10.1016/j.jvolgeores.2020.107076 . insu-03112971

\section{HAL Id: insu-03112971 https://hal-insu.archives-ouvertes.fr/insu-03112971}

Submitted on 1 Mar 2021

HAL is a multi-disciplinary open access archive for the deposit and dissemination of scientific research documents, whether they are published or not. The documents may come from teaching and research institutions in France or abroad, or from public or private research centers.
L'archive ouverte pluridisciplinaire HAL, est destinée au dépôt et à la diffusion de documents scientifiques de niveau recherche, publiés ou non, émanant des établissements d'enseignement et de recherche français ou étrangers, des laboratoires publics ou privés. 


\title{
Experimental constraints on pre-eruption conditions of the 1631 Vesuvius eruption
}

\author{
Ilaria Bardeglinu ${ }^{\text {a,b,c }}$, Raffaello Cioni ${ }^{\mathrm{a},}$, Bruno Scaillet ${ }^{\mathrm{c}}$ \\ ${ }^{\mathrm{a}}$ Earth Sciences Dept., University of Firenze, Italy \\ ${ }^{\mathrm{b}}$ Earth Sciences Dept., University of Pisa, Italy \\ ${ }^{c}$ Institut des Sciences de la Terre d'Orléans, CNRS-Université d'Orléans-BRGM, France \\ abstract
}

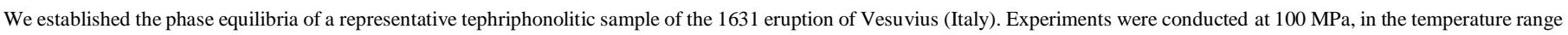

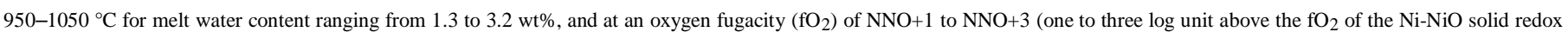

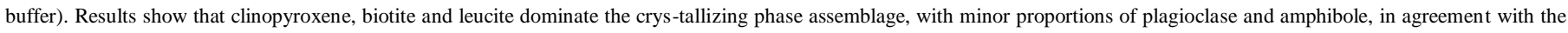

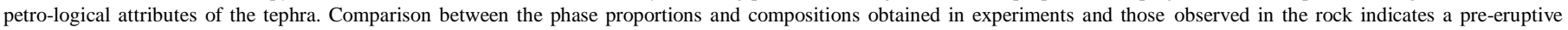

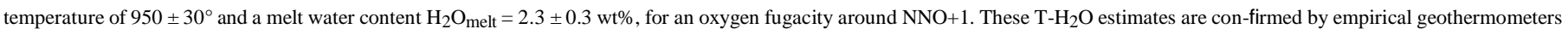

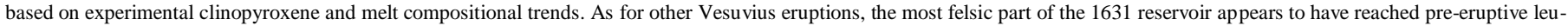

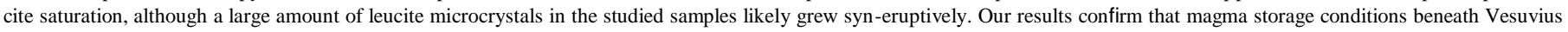
became hotter, shallower, and more $\mathrm{CO}_{2}$-rich after the $\mathrm{AD} 79$ Pompeii Plinian event.

\section{Introduction}

The knowledge of the range of possible styles of magmatic activity to be expected from renewed activity at active volcanoes like Somma-Vesuvius is a challenging task, yet such information is of first-order im-portance for volcanic hazard assessment and emergency planning. Magma composition and preeruptive physical conditions directly in-fluence magma rheology, volatile content and style of degassing. In turn, these strongly control the style of volcanic activity and the pre-eruptive state of the volcano, giving clues to interpret the precursory signals of an impending eruption (Blundy and Cashman, 2008; Rutherford, 2008; Cashman, 2004; Oppenheimer et al., 2014).

The study of the products of past eruptions, and the changes of magma composition with time, represent a viable way to infer the range of possible magma conditions for a reactivation of the volcanic ac-tivity. Experimental petrology conducted on these products may con-strain possible physicochemical conditions of pre-eruptive magma crystallization, as indicated by the general stability fields of the different mineralogical phases under variable conditions of pressure $\mathrm{P}$, tempera-ture $\mathrm{T}$ and volatile fugacity in the coexisting fluid phase.

\footnotetext{
Corresponding author.

E-mail address: raffaello.cioni@unifi.it (R.Cioni).
}

The last $20 \mathrm{ka}$ of activity at Somma-Vesuvius (Italy; SV) have been punctuated by several explosive eruptions, that dispersed widespread sheets of fallout deposits and often ravaged the volcano slopes and the plain nearby with pyroclastic density currents (Cioni et al., 2008). This fact, with the dreadfully high population density of the many villages encircling the volcano, only few kilometers far from the summit vent, make SV one of the higher risk volcanoes in the world.

SV products are characterized by a variable composition, from slightly evolved tephritic to phonolitic tephritic melts, which especially characterized the most recent activity, up to phonolites and trachytes, generally associated to the largest eruptions in terms of both Intensity and Magnitude (Pyle, 2015). A general perspective about the SV past ac-tivity clearly reveals that SV is a highly dynamic system, where the main compositional features of the magma and the frequency and style of eruptions show significant changes with time, at scales from millennia (for the oldest activity) to centuries (for the most recent activity; Cioni et al., 2008, Santacroce et al., 2008; Sbrana et al., 2020). In addition, the large set of available experimental petrology data (Scaillet et al., 2008; Pichavant et al., 2014) clearly suggests a progressive shallowing of the main magma reservoir with time, with two main levels of magma stalling at pressures of about $200 \mathrm{MPa}$ and $100 \mathrm{MPa}$ (about

$8 \mathrm{~km}$ and $4 \mathrm{~km}$ depth, respectively). This evidence is also confirmed by other different, independent datasets, such as the pressure 
inferences from chlorine in glass (Balcone-Boissard et al., 2016) or from water concentration in melt inclusions in the products of different erup-tions of Vesuvius (Cioni, 2000; Fulignati and Marianelli, 2007), or the available seismic tomography data (Auger et al., 2001; Scarpa et al., 2002). The deepest reservoir was active at least from 9 to $2 \mathrm{ka}$ ago, while the shallower was surely active during the last $2 \mathrm{ka}$ of activity, up to the last eruption in 1944. In this context, the definition of the main fields of physico-chemical conditions related to all the main erup-tions of SV, and especially to those which occurred during the last cen-turies of activity, can be of extreme importance for the definition of the possible range of expected magma composition and physical properties in the case of a next reactivation of the volcano. The present strategy adopted by the Dept. of Italian Civil Defense for SV to face a possible next renewal of activity is based on a so-called "Maximum Expected Event" scenario (Barberi et al., 1990; Cioni et al., 2003), considered to be a subplinian eruption (Subplinian I type in the classification of Cioni et al., 2008). Following the Plinian AD 79 event, the two largest events at SV, are of this type (AD 472, $A D$ 1631). While the products of the AD 472 eruption have already been the object of detailed studies aimed at defining PTX magma conditions (Scaillet et al., 2008; Fulignati and Marianelli, 2007), the products of the 1631 event are still not well studied in this respect. In the paper, we present experimental data on the mineral phase stability for this very important eruption, with the aim of constraining pre-eruptive storage conditions and physical prop-erties expected to control similar eruptive scenarios.

\section{The 1631 eruption}

The 1631 eruption is the last large explosive event of Vesuvius, which strongly impacted on the societal framework of the time and claimed from 1000 to more than 6000 casualties, according to different authors (Bertagnini et al., 2006; Rosi et al., 1993; Rolandi et al., 1993). The eruption started on 16 December 1631 and had several phases. Ac-cording to Rosi et al., 1993, after the opening of a radial fissure along the flanks of the cone, the eruption rapidly escalated to a subplinian phase, with the formation of a sustained convective plume issued from the central vent. The plume reached a maximum height of about $20 \mathrm{~km}$ and was dispersed to the East by the prevailing winds; ash fallout was directly recorded as far as Turkey. This activity was sustained for about 8 $\mathrm{h}$, during which about $0.1 \mathrm{~km}^{3}$ of DRE (dense rock equivalent) were erupted and a scoria fallout bed, up to several decimeters thick, de-posited. This phase shifted toward a pulsating, vulcanian-like activity characterized by a discontinuous and weakly sustained eruptive plume, which resulted in an alternation of ash and lithic-rich, lapilli-bearing beds, only deposited in very proximal outcrops. This activity was followed by a phase of low column fountaining, lasting at maxi-mum for $2 \mathrm{~h}$, during which several pyroclastic density current lobes dis-persed along the western and southern slopes of the volcano, rapidly reaching numerous surrounding villages. The eruption ended with a prolonged phase of semi-continuous ash emission; it deposited a widespread sheet of nearly impervious fine ash, which promoted the fre-quent formation of lahars and floods, possibly protracting for years the devastating effects of the eruption.

Contrary to other eruptions, the products of the 1631 event have not received dedicated petrological studies, apart from the recent paper of Stoppa et al. (2017) dealing with an extensive presentation and discus-sion of compositional data of juvenile material and skarn fragments from the metasomatic halo around the magma chamber. The tephra fallout deposit shows a general compositional zoning, ranging from tephritic phonolite at the base to phonolitic tephrite at top ( $\mathrm{MgO}$ vari-able from 2.4 to $6.2 \mathrm{wt} \%$ upsection). Macroscopically, juvenile material of the eruption is mainly represented by poorly to moderately vesicular, green scoria clasts, with a largely inhomogeneous vesicularity (in terms of shape and size) and characterized by the presence of coarse, idiomor-phic leucite crystals. A subordinate amount of moderately to highly ve-sicular, light green pumice is also present throughout the whole sequence of deposits, being more abundant in the basal samples. No sys-tematic compositional difference has been evidenced between these two types of juvenile material. The petrography of the samples is dom-inated by the ubiquitous presence of large crystals (up to $\mathrm{cm}$-sized) of leucite, mm-sized clinopyroxene (with both pale green, Mg-rich diop-side and dark, Fe-rich diopside present in variable proportions with re-spect to the stratigraphic position of the sample), minor dark mica and plagioclase. Apatite, FellTi oxides and garnet are present as accessory phases. The samples from the late stages of the plinian phase up to the pyroclastic density currents phase present a more complex mineralogy, with a larger amount of mafic phenocrysts (mainly diopside) and oliv-ine possibly derived from the partial disruption of the comagmatic, highly crystallized margin of the magma reservoir, admixed to varying degrees within the primary mineral paragenesis. Juvenile material from the very base of the eruption has a glass-bearing groundmass, which becomes much more crystalline in the later products. Ground-mass is mainly formed by leucite microcrystals, clinopyroxene and minor k-feldspar microlites set in a variable amount of glass. Microlites of microsommite, $\mathrm{a}\left(\mathrm{Cl}^{-}, \mathrm{SO}^{2}{ }_{4}^{-}\right)$- bearing mineral of the cancrinite group, are also commonly present.

In this view, the most suited products to investigate the pre-eruptive state of the 1631 magma are hence represented by the first erupted products. These present in fact a more homogeneous mineral paragen-esis and record the processes occurring in the upper part of the reser-voir, so giving information about the pre-eruptive conditions at top of the magma reservoir.

\section{Experimental and analytical techniques}

The experiments and ensuing analyses were performed using established laboratory procedures (e.g., Martel et al., 1998; Scaillet and Evans, 1999; Di Carlo et al., 2006; Cadoux et al., 2014; Andújar et al., 2015), which are briefly described below. The selected sample was ground and then fused twice at 1400 ${ }^{\circ} \mathrm{C}$ and 1 bar, in a Pt crucible in open atmosphere, with grinding in between. The resulting dry glass was ground to a mesh size of $20 \mu \mathrm{m}$ and used as starting material in all experiments. Gold capsules (inner $1.5 \mathrm{~mm}$, thickness $0.2 \mathrm{~mm}$, length $1.5-2 \mathrm{~cm}$ ) were prepared from Au tubing, after boiling them for a few minutes in a diluted $\mathrm{HCl}$ solution to remove any grease left over after tube production, then annealing them with a small torch up to red col-our for a few seconds. The capsules were first arc welded at their base, then loaded with distilled water, followed by silver oxalate as the source of $\mathrm{CO}_{2}$, and then by the silicate powder. The fluid $\left[\left(\mathrm{H}_{2} \mathrm{O}+\mathrm{CO}_{2}\right) /\right.$ silicate $]$ mass ratio was always kept at around 0.1. The initial mole fraction of water in the loaded fluid $\left(\mathrm{XH}_{2} \mathrm{O}\right.$ fluid $=\mathrm{H}_{2} \mathrm{O} /\left(\mathrm{H}_{2} \mathrm{O}+\mathrm{CO}_{2}\right)$, in moles) var-ied between 1 (water saturation) down to 0.4 . After being arc-welded shut, the capsules were weighed to check for volatile loss, and put in an oven at $100{ }^{\circ} \mathrm{C}$ for $15-30 \mathrm{~min}$ to homogenize the fluid distribution across the charges. Capsules were weighed again after the run to check for leaks. All capsules showing a weight difference less than $0.3 \mu \mathrm{g}$ were considered successful.

The experiments were performed in internally heated vessels (IHPV), pressurized with a mixture of $\mathrm{Ar}$ and $\mathrm{H}_{2}$ (Scaillet et al., 1992), to impose redox conditions around the $\mathrm{Ni}-\mathrm{NiO}$ redox curve $(\mathrm{NNO}+1$, or one log unit above NNO. The $\mathrm{H}_{2}$ pressure loaded at room temperature in the IHPV was 2.6-2.8 bar, which generates $\mathrm{fH}_{2}$ at the target P-T con-ditions in the range 5-8 bar, which corresponds to $\mathrm{fO}_{2}$ slightly above $\mathrm{NNO}$, in agreement with available $\mathrm{fO}_{2}$ constraints on mafic Vesuvius magmas (Pichavant et al., 2014). A further run was also performed at $950{ }^{\circ} \mathrm{C}$ with pure Ar, to generate more oxidized conditions $(\mathrm{NNO}+3)$. Temperature was monitored by $2 \mathrm{~S}$-type thermocouples and the gradi-ent of the hot spot zone across the charge location was less than $3{ }^{\circ} \mathrm{C}$. Pressure was monitored with a transducer calibrated against a Bourdon tube gauge, and is known to within $\pm 1 \mathrm{MPa}$, with daily fluctuations of less than $2 \mathrm{MPa}$, depending on room temperature. Run durations varied according to temperature, between 5 days at $950{ }^{\circ} \mathrm{C}$ down to $17 \mathrm{~h}$ at 
$1050{ }^{\circ} \mathrm{C}$. All except the NNO+3 experiments were ended using a drop quench device (Di Carlo et al., 2006), which ensures quench rates of about $150{ }^{\circ} \mathrm{C} / \mathrm{s}$.

A total of 29 successful charges were produced at $100 \mathrm{MPa}$, in the temperature range $950-1050{ }^{\circ} \mathrm{C}$. Each capsule was then opened, and half of the run product mounted in epoxy resin and polished for a first optical inspection. Samples were then carbon coated for inspection with a scanning electron microscope (SEM) and electron microprobe analyses (EPMA) of minerals and glass. The conditions for EPMA were: accelerating voltage of $15 \mathrm{kV}$, counting time on peak of $10 \mathrm{~s}$, sample cur-rent of $6 \mathrm{nA}$, using either a focused (minerals) or defocused $(5-10 \mu \mathrm{m}$, glass) beam. The glass analyses were corrected for alkali migration using in-house hydrous glass standards of known alkali and water con-tent. The same analytical conditions were used for the analyses of min-erals and glasses of the starting rock. The relative amounts of the different phases in the run products were calculated by mass balance using the XLFRAC program (Stormer and Nicholls, 1978). Analyses of backscattered electron SEM images using ImageJ software (Schneider et al., 2012) provided an additional estimate of the charge crystallinity. Volatiles $\left(\mathrm{H}_{2} \mathrm{O}\right.$ and $\left.\mathrm{CO}_{2}\right)$ dissolved in the melt were not directly mea-sured. The dissolved volatile contents $\left(\mathrm{H}_{2} \mathrm{O}\right.$ and $\left.\mathrm{CO}_{2}\right)$ of the quenched glasses were calculated using the solubility data obtained on similar phonotephritic melts by Behrens et al. (2009). Specifically, we have used their $\mathrm{H}_{2} \mathrm{O}$ and $\mathrm{CO}_{2}$ data obtained in the pressure range 50-200 MPa to derive empirical solubility laws for these two species in phonotephritic melts. The functional relationships relating fugacities to volatile contents read as follows:

f $\mathrm{H}_{2} \mathrm{O} 1 / 4$ 60:292 ðwt $\% \mathrm{H}_{2} \mathrm{O}_{\text {melt }} P^{2} p$ 113:157 wt $\% \mathrm{H}_{2} \mathrm{O}_{\text {melt }}$

and

$\mathrm{fCO}_{2} 1 \frac{1}{4} 1: 46 \quad 10^{4} \quad$ oppmCO 2 -melt $\mathrm{P}^{2}$ p 6:093 $10^{1} \quad$ ppmCO $_{2}$-melt

The fugacities of pure $\mathrm{H}_{2} \mathrm{O}$ and $\mathrm{CO}_{2}$ were calculated using a modified Redlich-Kwong equation of state (Holloway, 1987) and the Lewis and Randall rule was used to compute fugacities of $\mathrm{H}_{2} \mathrm{O}-\mathrm{CO}_{2}$ fluid mixtures. With these equations, knowing the amount of crystallization, the mass of silicate glass, the $\mathrm{H}_{2} \mathrm{O}$ and $\mathrm{CO}_{2}$ loaded to the capsule, the final fluid composition of each charge can be calculated, along with the corre-sponding $\mathrm{H}_{2} \mathrm{O}_{\text {melt }}$ and $\mathrm{CO}_{2}$-melt, assuming thermodynamic equilibrium between fluid and melt and using mass balance constraints. The calcu-lated values of $\mathrm{XH}_{2} \mathrm{O}$ fluid-final, $\mathrm{wt} \% \mathrm{H}_{2} \mathrm{O}_{\text {melt }}$ and $\mathrm{ppmCO}_{2}$ melt are reported in Table 2, along with the initial mole fraction of fluid loaded to the cap-sule. As expected, the final fluid composition is $\mathrm{CO}_{2}$ richer compared to that loaded to the capsule, as a consequence of the higher solubility of $\mathrm{H}_{2} \mathrm{O}$ in silicate melts, relative to that of $\mathrm{CO}_{2}$. From the calculations, it ap-pears that a plot $\mathrm{XH}_{2} \mathrm{O}$ fluid vs wt $\% \mathrm{H}_{2} \mathrm{O}_{\text {melt }}$ of all charges defines a single linear trend as follows:

\section{$\mathrm{H}_{2} \mathrm{O}_{\text {melt }}$ ठwt\%P 1/4 3:1265 X $\mathrm{XH}_{2} \mathrm{O}_{\text {fluid-final }}$ p 0:0511 $\mathrm{R}^{2}$ 1/4 0:9944}

Similarly, $\mathrm{XH}_{2} \mathrm{O}$ fluid is highly correlated to $\mathrm{XH}_{2} \mathrm{O}$ fluid-final:

\section{$\mathrm{XH}_{2} \mathrm{O}_{\text {fluid-final }}$ 1/4 1:2247 $\quad \mathrm{XH}_{2} \mathrm{O}_{\text {fluid }}-0: 2468 \mathrm{R}^{2}$ 1/4 0:9888}

We caution that these two empirical relationships are specific to our experimental conditions and procedure (i.e., the amount of volatiles loaded to the capsules, total pressure and the amount of crystallization) and should not be applied to other contexts. In what follows, we primar-ily use the parameter $\mathrm{XH}_{2}$ Ofluid to plot our data, since it is the one vari-able of the system actually controlled, whereas both $\mathrm{XH}_{2} \mathrm{O}$ fluid-final and $\mathrm{H}_{2} \mathrm{O}_{\text {melt }}$ are calculated values. We nevertheless use the above relation-ships to show the correspondence between equilibrium (final) fluid composition and melt $\mathrm{H}_{2} \mathrm{O}$ contents in our experiments whenever needed.

\section{Bulk rock, mineral and glass composition of the analyzed sample}

The 1631 products show a compositional variability from more evolved, tephritic-phonolites at the base of the lapilli fallout sequence up to less evolved phonolitic-tephrites at top (Rosi et al., 1993; Santacroce et al., 2008; Stoppa et al., 2017). Similar gradients have been classically interpreted at Vesuvius as the result of the interplay be-tween the eruption dynamics and the tapping of a vertically zoned magma reservoir (Civetta et al., 1991; Cioni et al., 1998). Alternative ex-planations for the observed compositional variability, like the effects of a variable crystal content in the juvenile material, have been generally discarded as they can be hardly reconciled with the regular variability of magma composition observed in the products. The analyzed products were collected from the thin bed at the base of the eruption sequence (basal crystalrich sand fallout of Rosi et al., 1993) at a proximal site $4.5 \mathrm{~km}$ East of the Vesuvius crater, characterized by the presence of a very high concentration (about $25 \mathrm{wt} \%$ ) of mm-sized, loose crystals of leucite and pyroxene. An aliquot of light green pumice lapilli was se-lected for the experiments (Table 1). The analyzed material has a tephritic-phonolite composition, representative of the most evolved end-member of the whole eruption sequence, in agreement with litera-ture compositions. The phenocryst paragenesis is less complex with respect to the following products, being dominated by clinopyroxene, minor leucite and lower amounts of biotite and plagioclase. The total phenocryst content is about $20-30 \%$ vol. Fine lapilli and loose crystals from the coarse ash fraction of this bed were also separated, thin sec-tioned and polished for further compositional analyses of phenocrysts, groundmass glass and microlites. Melt inclusions in selected pheno-crysts of leucite and clinopyroxene were also analyzed.

\subsection{Mineral composition}

Representative compositions of minerals and glasses from the natu-ral sample are given in Tables S1 to S7 of the Supplementary Materials (SM). Clinopyroxene $(\mathrm{Cpx})$ is the most abundant phase and shows a range of compositions (En 15-41 Fs 9-34 Wo 49-53; Table S1). Despite the presence of strongly zoned crystals, at least two populations of $\mathrm{Cpx}$ can be still recognized, as typical for many Vesuvius eruptions (Cioni et al., 1998), with a prevalence of high $\mathrm{Mg}$-Diopside. As in other eruptive products of Vesuvius, $\mathrm{Cpx}$ is rich in $\mathrm{Al}_{2} \mathrm{O}_{3}$ (from 3 up to 12 wt \%; Fig. 1 and Table S1) and $\mathrm{TiO}_{2}$ (0.5-2.4 wt\%; Fig. 1 and Table $\mathrm{S} 1$ ), with a $\mathrm{Mg} / \mathrm{Mg}+\mathrm{Fe}_{\mathrm{T}}$ (on a molar base) varying between 0.3 up to over 0.8 . The large variation of clinopyroxene composition (Fig. 1, Table $1 \mathrm{SM}$ ), and the complex zoning often observed in the natural Cpx phenocrysts (Fig. 2) indicate either crystallization under different physicochemical conditions, or the possible occurrence of overgrown xenocrysts. These could derive from magma mixing following mafic

Table 1

Bulk composition of the starting material 1631 SG compared with literature natural compositions. v40 - Crystal rich basal sand layer (Rosi et al., 1993); AS94-314 - Crystal rich basal sand layer (Santacroce et al., 2008); 1631 SG - Starting glass for phase-equilibrium experiments (EPMA analyses; average and standard deviation, in italic, of 30 analyzed spots).

\begin{tabular}{lrrrr}
\hline & $\mathrm{v} 40$ & AS96-314 & $1631 \mathrm{SG}$ & \\
\hline $\mathrm{SiO}_{2}$ & 52.00 & 52.06 & 51.61 & 0.30 \\
$\mathrm{TiO}_{2}$ & 0.71 & 0.70 & 0.71 & 0.07 \\
$\mathrm{Al}_{2} \mathrm{O}_{3}$ & 19.46 & 19.31 & 19.03 & 0.20 \\
$\mathrm{FeO}$ & 5.47 & 5.44 & 5.58 & 0.23 \\
$\mathrm{MnO}$ & 0.14 & 0.14 & 0.12 & 0.08 \\
$\mathrm{MgO}$ & 1.93 & 2.42 & 2.56 & 0.10 \\
$\mathrm{CaO}$ & 7.71 & 7.20 & 8.27 & 0.18 \\
$\mathrm{Na} 2 \mathrm{O}$ & 3.90 & 4.18 & 3.95 & 0.11 \\
$\mathrm{~K}_{2} \mathrm{O}$ & 8.25 & 8.10 & 7.67 & 0.14 \\
$\mathrm{P}_{2} \mathrm{O}_{5}$ & 0.42 & 0.44 & 0.49 & 0.08 \\
$\mathrm{Total}$ & 100.00 & 100.00 & 100.00 & \\
\hline
\end{tabular}



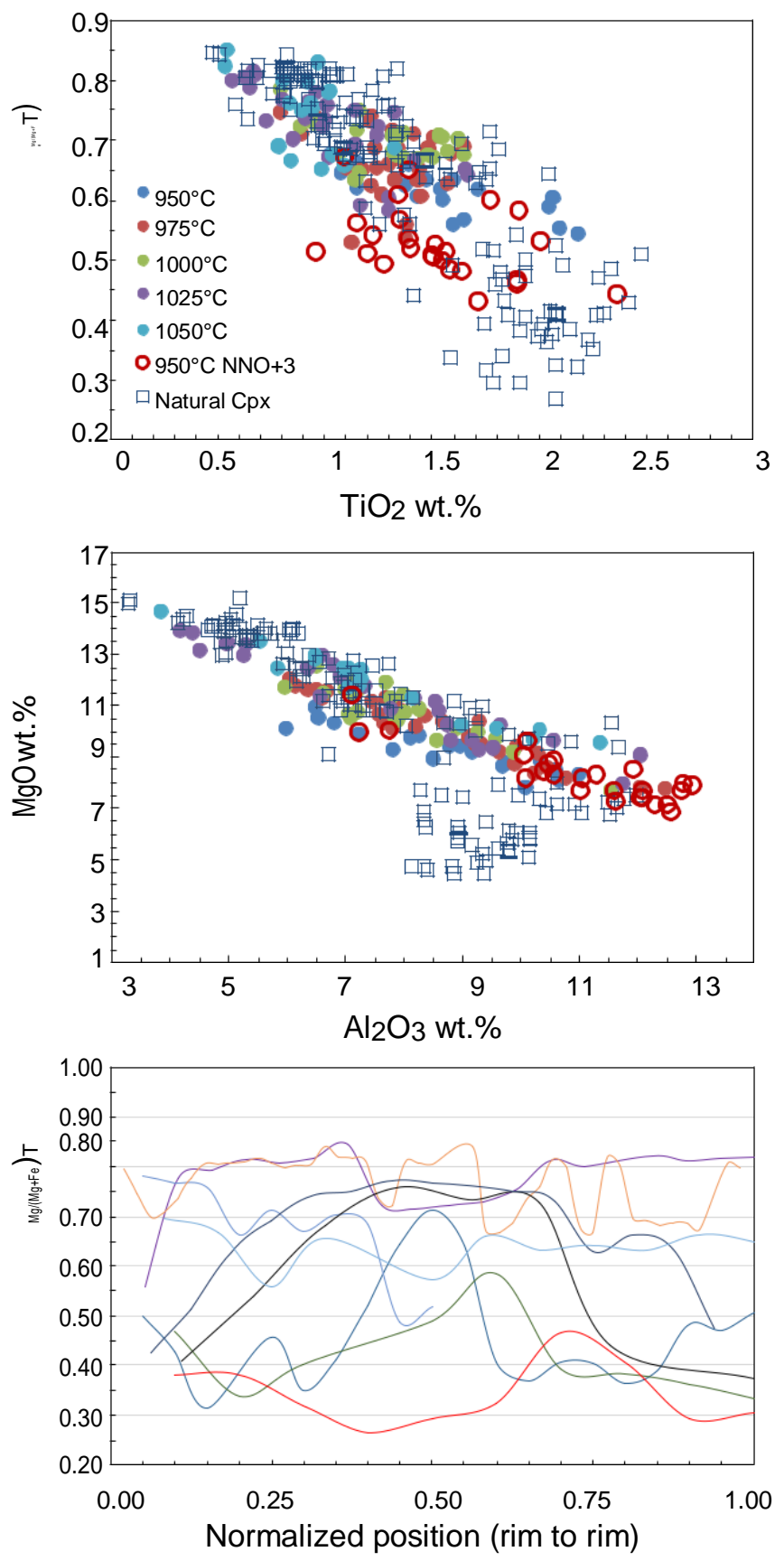

Fig. 1. Composition of experimental and natural clinopyroxene. Binary variation diagrams of (a) $\left(\mathrm{Mg} / \mathrm{Mg}+\mathrm{Fe}\right.$ ) vs. $\mathrm{TiO}_{2}$ and $\mathrm{MgO}$ vs. $\mathrm{Al}_{2} \mathrm{O}_{3}$. Composition of natural $\mathrm{Cpx}$ (open squares) is plotted with composition of experimentally synthetized Cpx (colored dots b); c) Cpx zoning, shown along rim-to rim profiles of single, mm-sized phenocrysts.

recharge of the reservoir and/or from the disruption of the crystallized margins of the magma reservoir and of the thermometamorphic-metasomatized host rocks (Cioni et al., 1995; Stoppa et al., 2017). This compositional variation is also clearly visible from the analysis of single phenocrysts, in which $\mathrm{Mg}$-rich phenocrysts may, or may not, be rimmed by Mg-poor compositions (Figs. 1b; 2), suggesting different crystalliza-tion history for those $\mathrm{Mg}$-rich Cpx.

A few phenocrysts with values of $\mathrm{Mg} /(\mathrm{Mg}+\mathrm{Fe})$ lower than 0.45 are also characterized by largely scattered, high $\mathrm{TiO}_{2}$ concentrations
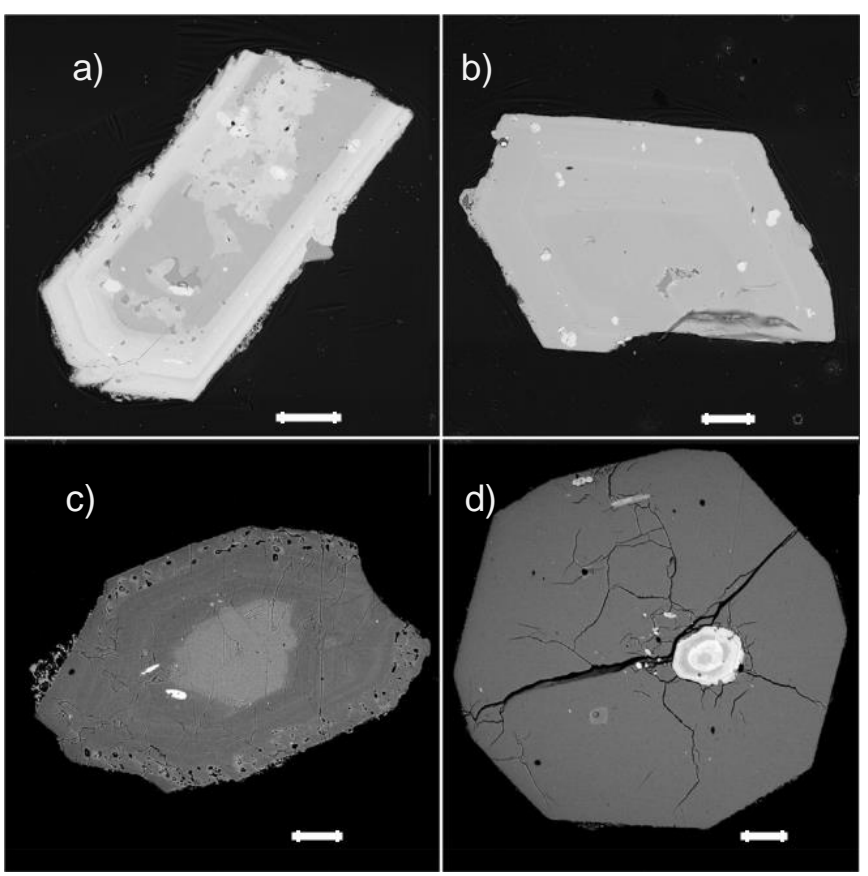

Fig. 2. BS-SEM photos of minerals in the natural paragenesis. a), b), c) differently zoned Cpx crystals; d) leucite phenocryst with a large inclusion of multiply zoned Cpx (white bar $=200 \mu \mathrm{m}$ ).

(1.5-2.5 wt $\%$ ), and variable $\mathrm{Al}_{2} \mathrm{O}_{3}$, between 8 and $13 \mathrm{wt} \%$. These compositions clearly deviate from the otherwise regular inverse relation be-tween $\mathrm{TiO}_{2}$ (or $\mathrm{Al}_{2} \mathrm{O}_{3}$ ) and $\mathrm{Mg} /(\mathrm{Mg}+\mathrm{Fe}$ ), suggesting the possible presence of xenocrysts/antecrysts crystallized under different condi-tions. Crystal zoning is generally oscillatory or direct (Mg-rich cores), while reverse zoning is less common (Fig. 1c). The complex zoning pat-terns of Mg-rich Cpx (Figs. 1b, 2a) have been interpreted at Vesuvius as the combined effects of repeated recharge and cooling cycles affecting the reservoir (Cioni et al., 1998).

Leucite ( $\mathrm{Lc}$ ) is the second most abundant phase, displaying a signif-icant range in crystal size, from mm-sized phenocrysts down to 50-200 $\mu \mathrm{m}$ microphenocrysts or microlites, all being generally homoge-neous in composition (Table S2). Lc phenocrysts have generally $0.8-0.9$ wt $\% \mathrm{Na}_{2} \mathrm{O}$ (equivalent to $93-94 \mathrm{~mol} \% \mathrm{Lc}$ ), while smaller individ-uals display slightly higher $\mathrm{Na}_{2} \mathrm{O}$ contents $(1.2-1.3 \mathrm{wt} \%$ or $91-92 \% \mathrm{Lc}$; Table S2). Plagioclase (Pl) occurs as single large crystals $(0.5-1 \mathrm{~mm})$, generally carrying a number of inclusions of Lc, apatite (Ap) and rare sanidine. They display normal zoning, from An81-88 in the core to An51-64 in the rim (Table S3). Biotite (Bt) occurs as single euhedral large crystals $(0.2-1 \mathrm{~mm})$. It is characterized by high $\mathrm{TiO}_{2}$ and $\mathrm{Al}_{2} \mathrm{O}_{3}$ contents (3-4.5 and $16 \mathrm{wt} \%$, respectively), significant amount of $\mathrm{F}$ $(0.7-1.3 \mathrm{wt} \%)$, being practically unzoned with respect to its $\mathrm{Mg} /\left(\mathrm{Mg}+\mathrm{Fe}_{\mathrm{T}}\right)$ (0.70-0.78; Table S4). FellTi oxides often occur along the boundaries of phenocrysts, in particular Cpx. They are magnetite (Mt) with ulvospinel (Usp) content of 17-19\% (Table S5), with an oscillatory zoning across the mineral. Only one rounded, partially resorbed crystal of amphibole (Amph) was found included in a leucite crystal and ana-lyzed: it is a FellMg calcic amphibole with high $\mathrm{K}_{2} \mathrm{O}$ content $(2.5 \mathrm{wt} \%$ ). A few glassy melt inclusions (MI) were also analyzed, mostly hosted in $\mathrm{Cpx}$ with $\mathrm{Mg} /(\mathrm{Mg}+\mathrm{Fe})$ between 0.50 and 0.78 , Lc and occasionally

in Pl. These MI were recalculated in order to account for host crystalliza-tion, using for MI hosted in Cpx an equilibrium $\mathrm{K}_{\mathrm{D}}(\mathrm{Fe}-\mid \mathrm{MMg})^{\mathrm{cpx} / \mathrm{melt}}$ of 0.28 (Putirka, 2008). MI hosted in Lc were recalculated using the same $\mathrm{K}_{2} \mathrm{O} / \mathrm{Na}_{2} \mathrm{O}$ ratio of 1.9 of the starting material (Table 1), assuming that leucite phenocrysts crystallized from this or similar melts. All the MI 
were characterized by a relative amount of host crystallization variable between 10 and $25 \mathrm{wt} \%$. After this correction, MI composition is rather homogeneous from crystal to crystal, reaching potassium-rich phono-lite composition $\left(\mathrm{SiO}_{2}\right.$ $=53.3-57.4 \mathrm{wt} \%, \mathrm{Al}_{2} \mathrm{O}_{3}=19.1-21.9 \mathrm{wt} \%, \mathrm{~K}_{2} \mathrm{O}=7.3-10.6 \mathrm{wt} \%$, on an anhydrous basis), with $\mathrm{MgO}$ generally lower than $1 \mathrm{wt} \%$ (Table $6 \mathrm{SM}$ ). The raw totals vary between 94.4 and $97.5 \mathrm{wt} \%$, with an average value of $96.4 \mathrm{wt} \%$

(Table S6), suggesting a concentration of dissolved $\mathrm{H}_{2} \mathrm{O}$ around 2-5 wt $\%$, in addition to generally high concentrations of $\mathrm{F}$ and $\mathrm{Cl}$ (up to $>1 \mathrm{wt} \%$ ). Compared to MI, the groundmass glasses are characterized above all by a significantly lower content in $\mathrm{K}_{2} \mathrm{O}$ (4.9-6.8 wt\%), reflecting the late, massive crystallization of Lc, and by a higher raw total (around $98 \mathrm{wt} \%$ ) and somewhat lower contents in $\mathrm{F}(0.2-0.4 \mathrm{wt} \%)$ (Table $7 \mathrm{SM})$.

\section{Experimental results} 2.

The details of experimental conditions and run products are given in Table

Phases identified include quenched glass (Gl), Cpx, Lc, Bt, Pl and fluid (fl), the latter evidenced by the presence of vesicles of 10-100 $\mu \mathrm{m}$ size evenly dispersed across the charge. Mineral size varies from a few tens ( $\mathrm{Lc}, \mathrm{Bt})$ down to a few $\mu \mathrm{m}(\mathrm{Cpx})$, being in general evenly distributed throughout the charges, though locally Cpx may define random mosaic patterns, possibly recording former grain boundaries, where phase nu-cleation was enhanced. The dominant phase is always Cpx, reaching up to $25 \mathrm{wt} \%$ under the investigated conditions, followed by leucite (6-10.4 wt $\%$ ), and biotite (2-5 wt $\%)$. Pl is always subordinate, with abundances not exceeding a few wt $\%$ in the explored $\mathrm{T}$ $\mathrm{XH}_{2}$ Ofluid inter-val (Table 2). The $\mathrm{XH}_{2} \mathrm{O}$ fluid-final values range from 1 down to 0.26 .

\subsection{Phase relationships}

The phase relationships of the worked sample are displayed on Fig. 3 in an isobaric, $\mathrm{T}-\mathrm{XH}_{2} \mathrm{O}$ fluid section. The correspondence with the final fluid composition is also indicated. The corresponding dissolved $\mathrm{H}_{2} \mathrm{O}$ contents $\left(\mathrm{H}_{2} \mathrm{O}_{\text {melt }}\right.$ ) are reported for the different temperatures in Table 2 (and indicated in Fig. 3 for $\mathrm{T}=950{ }^{\circ} \mathrm{C}$ ), as calculated following the procedure given above. Note that for some of the driest charges, Lc and Pl phases could not be formally identified and are only suspected.
For the different experimental conditions, $\mathrm{H}_{2} \mathrm{O}_{\mathrm{m}}$ varies from $3.2 \mathrm{wt} \%$ $\left(\mathrm{XH}_{2} \mathrm{O}\right.$ fluid $=\mathrm{XH}_{2} \mathrm{O}$ fluid/final $\left.=1\right)$ to $1.3 \mathrm{wt} \%\left(\mathrm{XH}_{2} \mathrm{O}\right.$ fluid-final $=0.3$; Table 2). These values can be affected by a large uncertainty and should be considered as indicative of the real content of dissolved volatiles. Available experimental constraints on $\mathrm{H}_{2} \mathrm{O}$ solubility for a more evolved potassic phonolite give similar values of $\mathrm{H}_{2} \mathrm{O}_{\mathrm{m}}$ at saturation in this P-T interval, around $3.5 \mathrm{wt} \%$ (Iacono-Marziano et al., 2007; Schmidt and Behrens, 2008). Conversely, experimental data of Di Matteo et al. (2004) for a trachy-phonolitic melt near $850{ }^{\circ} \mathrm{C}$ give higher values, around $4.8 \mathrm{wt} \%$, suggesting an important compositional control on the solubilities of the two alkaline melts. For dissolved $\mathrm{CO}_{2}$, calculated values go slightly over $1220 \mathrm{ppm}$ for the $\mathrm{CO}_{2}$-richest fluids (Table 2).

In addition to phase boundaries, estimated crystal proportions, based on mass balance calculations are also reported. Data derived from image analysis of the run products largely confirm these results (Table 2). The position of the solidus has not been bracketed by our ex-periments and is only tentatively shown.

Cpx is always the liquidus phase, crystallizing at $\mathrm{H}_{2} \mathrm{O}_{\text {melt }}$ saturation slightly over $1025^{\circ} \mathrm{C}$, being also the phase present everywhere in the di-agram below its liquidus (i.e., there is no $\mathrm{Cpx}$ consuming reaction down temperature

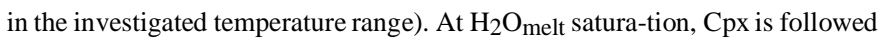
at lower temperature by $\mathrm{Bt}$, which crystallizes at around $980{ }^{\circ} \mathrm{C}$. The $\mathrm{Bt}$ stability curve has rather flat positive slope in this projection, breaking down at $\mathrm{H}_{2} \mathrm{O}_{\text {melt }}<2.3 \mathrm{wt} \%$ at $975{ }^{\circ} \mathrm{C}$, or when $\mathrm{H}_{2} \mathrm{O}_{\text {melt }}<1.3 \mathrm{wt} \%$ at $950{ }^{\circ} \mathrm{C}$. The tectosilicates ( $\mathrm{Lc}$ and $\mathrm{Pl}$ ) occur only in the $\mathrm{H}_{2} \mathrm{O}$-undersaturated portion of the section. At $1050{ }^{\circ} \mathrm{C}$, Lc ap-pears first, at $\mathrm{H}_{2} \mathrm{O}_{\text {melt }}=1.6 \mathrm{wt} \%$, then $\mathrm{Pl}$ at $\mathrm{H}_{2} \mathrm{O}_{\text {melt }}$ $=1.3 \mathrm{wt} \%$. At $950{ }^{\circ} \mathrm{C}$, this order of crystallization is reversed with $\mathrm{Pl}$ appearing first $\left(\mathrm{H}_{2} \mathrm{O}_{\text {melt }}=3 \mathrm{wt} \%\right)$, then $\mathrm{Lc}\left(\mathrm{H}_{2} \mathrm{O}_{\text {melt }}=2.5 \mathrm{wt} \%\right)$. The $\mathrm{Lc}$ and $\mathrm{Pl}$ curves cross over at $1000{ }^{\circ} \mathrm{C}$ and $\mathrm{H}_{2} \mathrm{O}_{\text {melt }}=2 \mathrm{wt} \%$. The phase diagram indicates that Bt crys-tallization in the 1631 magma investigated here requires temperatures below $1000{ }^{\circ} \mathrm{C}$. Amphibole was detected as few scattered crystals only in some charges at 1000 and $1025^{\circ} \mathrm{C}$ (Table 2), and its stability field is tentatively drawn here, being characterized by a lower-T stability limit, with Amph possibly reacting out to $\mathrm{Cpx}$, and $\mathrm{Bt}$ at $\mathrm{T}<1000{ }^{\circ} \mathrm{C}$. The closing of the Amph stability field at low temperature has been also documented in the phase equilibrium study of Vesuvius phonolites (Scaillet et al., 2008), where Amph breaks down to garnet in those more felsic magmas as temperature drops.

Table 2

Experimental conditions, run products and phase proportions (wt\%) estimated from mass balance calculations (in brackets values in vol\% from image analysis). All the experiments in the table were run at $\mathrm{P}=100 \mathrm{MPa}$ and under $\mathrm{fO}_{2}$ conditions of $\mathrm{NNO}+1 . \mathrm{XH}_{2} \mathrm{O}$ fluid final, $\mathrm{H}_{2} \mathrm{O}_{\text {melt }}$ and $\mathrm{CO}_{2} \mathrm{~m}$ calculated as described in the text $(\mathrm{p}=$ present but not quantified).

\begin{tabular}{|c|c|c|c|c|c|c|c|c|c|c|c|c|c|}
\hline Run & $\mathrm{T}^{\circ} \mathrm{C}$ & $\mathrm{XH}_{2} \mathrm{O}_{\mathrm{fl}}$ & $\mathrm{XHO}_{2}$ fl-final & $\mathrm{H}_{2} \mathrm{O}_{\mathrm{m}}$ & $\mathrm{CO}_{2 \mathrm{~m}}$ & Glass & Vesicles & $\mathrm{Cpx}$ & $\mathrm{Pl}$ & $\mathrm{Lc}$ & $\mathrm{Bt}$ & Other & $\mathrm{R}^{2}$ \\
\hline V1631 20 & 950 & 1 & 1 & 3.23 & 0 & $79.0(81)$ & (0) & $18.9(17)$ & & & $2.1(2)$ & & 0.93 \\
\hline V1631 21 & 950 & 0.93 & 0.90 & 2.85 & 180 & $76.8(76)$ & (4) & $20.6(15)$ & (5) & & $2.6(2)$ & & 0.71 \\
\hline V1631 22 & 950 & 0.83 & 0.76 & 2.56 & 425 & $77.0(74)$ & (18) & $21.2(16)$ & (4) & & $1.8(1)$ & & 0.71 \\
\hline V1631 23 & 950 & 0.7 & 0.60 & 2.20 & 676 & $75.1(71)$ & (12) & $22.3(19)$ & (3) & (3) & $2.6(0.5)$ & & 0.28 \\
\hline V1631 24 & 950 & 0.44 & 0.36 & 1.55 & 1014 & $60.5(65)$ & (17) & $25.3(14)$ & (8) & (7) & $2.7(0.5)$ & & 0.81 \\
\hline V1631 15 & 975 & 1 & 1 & 3.23 & 0 & $83.6(82)$ & $(0)$ & $11.7(17)$ & & & $4.7(2)$ & & 2.23 \\
\hline V1631 16 & 975 & 0.94 & 0.92 & 2.92 & 166 & $83.6(82)$ & (5) & $13.9(16)$ & & & $2.5(1)$ & & 0.52 \\
\hline V1631 17 & 975 & 0.83 & 0.76 & 2.60 & 439 & $81.4(85)$ & (12) & $15.8(12)$ & & & $2.7(0.5)$ & & 1.27 \\
\hline V1631 18 & 975 & 0.73 & 0.57 & 2.17 & 733 & $81.5(82)$ & (8) & $18.5(16)$ & $(0.5)$ & & & & 2.23 \\
\hline V1631 19 & 975 & 0.38 & 0.26 & 1.27 & 1167 & $68(72)$ & (4) & $23.5(13)$ & $(8)$ & $8.5(7)$ & & & 1.14 \\
\hline V1631 01 & 1000 & 1 & 1 & 3.23 & 0 & 89.7 (85) & (2) & $10.3(15)$ & & & & & 3.12 \\
\hline V163102 & 1000 & 0.93 & 0.89 & 2.92 & 211 & $89.4(82)$ & (8) & $10.6(17)$ & & & & & 2.25 \\
\hline V163103 & 1000 & 0.83 & 0.76 & 2.63 & 457 & $87.8(85)$ & (9) & $12.2(14)$ & & & & & 0.74 \\
\hline V163104 & 1000 & 0.73 & 0.63 & 2.35 & 662 & 86.7 (83) & (12) & $13.3(15)$ & & & $(0.5)$ & Amph & 0.2 \\
\hline V163105 & 1000 & 0.47 & 0.33 & 1.54 & 1102 & $78.5(81)$ & (8) & $15.8(14)$ & $\mathrm{p}$ & $5.7(3)$ & & Amph & 0.74 \\
\hline V1631 10 & 1025 & 1 & 1 & 3.23 & 0 & $96.4(91)$ & (0) & $3.6(9)$ & & & & Amph & 2.13 \\
\hline V1631 11 & 1025 & 0.93 & 0.90 & 2.98 & 206 & $94.9(90)$ & (0) & $5.1(10)$ & & & & Amph & 3.29 \\
\hline V1631 12 & 1025 & 0.84 & 0.77 & 2.71 & 441 & $95(91)$ & (5) & $5(8)$ & & & & & 1.28 \\
\hline V1631 13 & 1025 & 0.76 & 0.64 & 2.41 & 661 & 91.7 (88) & (3) & $8.3(11)$ & & & & Amph & 0.79 \\
\hline V1631 14 & 1025 & 0.44 & 0.27 & 1.33 & 1223 & $88.9(90)$ & (2) & $11.1(10)$ & & $\mathrm{p}$ & & Amph & 0.91 \\
\hline V163106 & 1050 & 1 & 1 & 3.23 & 0 & $100(100)$ & $(0)$ & & & & & & \\
\hline V163107 & 1050 & 0.91 & 0.86 & 2.94 & 289 & 100 & (0) & & & & & & \\
\hline V163108 & 1050 & 0.83 & 0.74 & 2.67 & 519 & $98.9(99)$ & (0) & $1.1(1)$ & & & & & 1.01 \\
\hline V1631 09 & 1050 & 0.66 & 0.51 & 2.12 & 890 & 97 (97) & (1) & $3(3)$ & & & & & 1.12 \\
\hline V1631 10A & 1050 & 0.43 & 0.29 & 1.42 & 1228 & (70) & (6) & $6.6(7)$ & $7.27(10)$ & $8.5(12)$ & & & \\
\hline
\end{tabular}




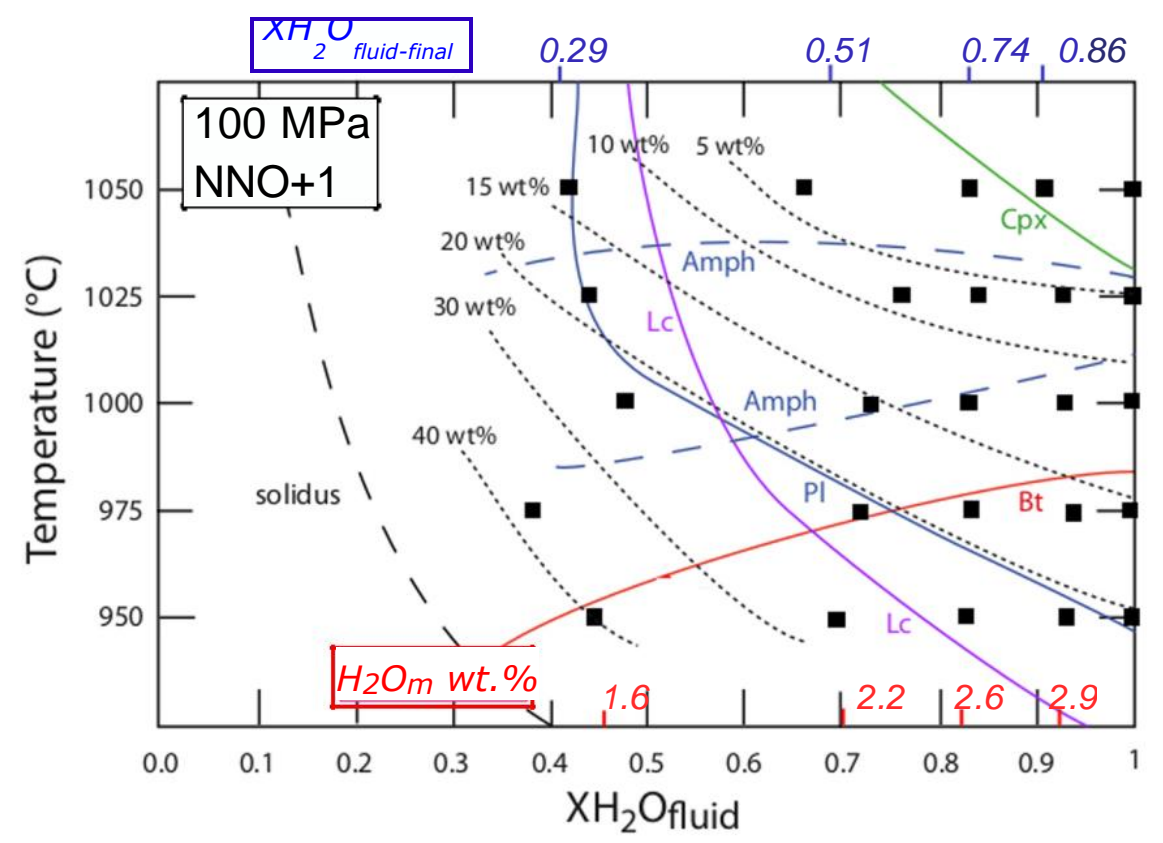

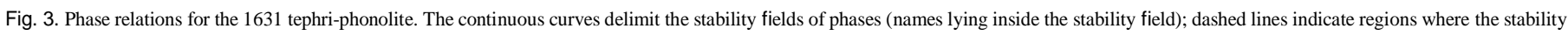

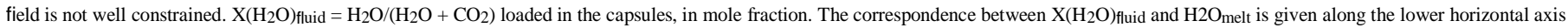

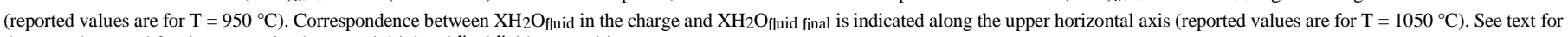
the procedure used for the conversion between initial and final fluid composition.

\subsection{Phase compositions}

\subsubsection{Clinopyroxene}

Experimental Cpx are diopside according to the classification scheme of Morimoto (1988), with $\mathrm{Mg} /(\mathrm{Mg}+\mathrm{Fe}$ ) ranging between 0.55 and 0.8 (Table $\mathrm{S} 8$ ). The main compositional variations concern $\mathrm{Ti}, \mathrm{Al}, \mathrm{Fe}$ and $\mathrm{Mg}$, which are all significantly affected by temperature changes, and less so by variations of $\mathrm{XH}_{2} \mathrm{O}$ fluid (Fig. 4).

In particular (Fig. 1), Cpx produced at $1025-1050{ }^{\circ} \mathrm{C}$ has 11.7-13.5 wt $\% \mathrm{MgO}$, while at $950{ }^{\circ} \mathrm{C}, \mathrm{MgO}$ does not exceed 8-10 wt $\%$. Both $\mathrm{Al}_{2} \mathrm{O}_{3}$ and $\mathrm{TiO}_{2}$ increase as temperature decreases, the latter from around 1 wt $\%$ at $1050{ }^{\circ} \mathrm{C}$, up to $2 \mathrm{wt} \%$ at $950{ }^{\circ} \mathrm{C}\left(5.5-7.6 \mathrm{wt} \% \mathrm{Al}_{2} \mathrm{O}_{3}\right.$ at $1050{ }^{\circ} \mathrm{C}$ up to $8-10.5 \mathrm{wt} \%$ at $\left.950^{\circ} \mathrm{C}\right)$.

A thermometric relationship is established on the basis of $\mathrm{Cpx}$ com-position $\left((\mathrm{Mg} /(\mathrm{Mg}+\mathrm{Fe}))\right.$, showing an important linear relationship $\left(\mathrm{R}^{2}=0.83\right)$ with $\mathrm{T}$, with only a second order relationship with

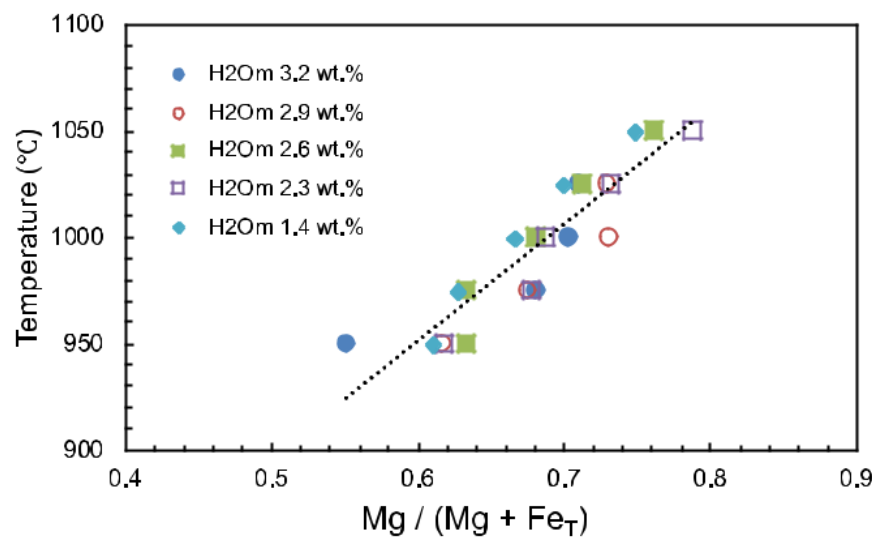

Fig. 4. Compositional variability of $\mathrm{Cpx}$ with temperature and water content of the melt. Symbols are for experiments run under similar initial $\mathrm{XH}_{2} \mathrm{O}$ fluid conditions (average water content in the glass indicated in legend; see Table 2).
$\mathrm{H}_{2} \mathrm{O}_{\text {melt }}$. The empirical geothermometer relationships, using Cpx pro-duced at $\mathrm{NNO}+1$, is as follows:

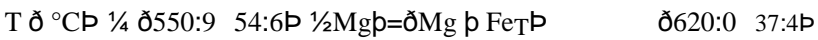

The standard error of the regression is $14.5^{\circ} \mathrm{C}$, with a maximum dif-ference between estimated and measured $\mathrm{T}$ of $26{ }^{\circ} \mathrm{C}$. The choice of a quadratic regression, or the addition of a factor accounting for $\mathrm{H}_{2} \mathrm{O}_{\text {melt }}$ do not significantly improve the results.

\subsubsection{Leucite}

Analyzed Lc are listed in Table S9; as expected, Lc does not show any significant compositional variation with experimental parameters.

\subsubsection{Mica}

Analyzed Bt are listed in Table S10. The analyzed mica straddles the biotite-phlogopite divide line in the siderophyllite-annite-eastonite-phlogopite quadrilateral, with mica produced at $950{ }^{\circ} \mathrm{C}$ being biotite, while mica from experimental charges at $975^{\circ} \mathrm{C}$ being true phlogopite, and plotting very close to most of the observed natural compositional variability. Biotite is otherwise characterized by elevated $\mathrm{TiO}_{2}$ contents, from 3 up to near $6 \mathrm{wt} \%, \mathrm{TiO}_{2}$ steadily increasing as $\mathrm{XH}_{2} \mathrm{O}$ fluid decreases (Fig. 6). Conversely, its $\mathrm{MgO}$ content increases with increasing water content.

\subsubsection{Plagioclase}

Analyzed Pl are listed in Table S11. Pl crystals $(\mathrm{An70} \pm 2)$ were clearly identified and analyzed only in the $\mathrm{H}_{2} \mathrm{O}$-poorest, $1050{ }^{\circ} \mathrm{C}$ run $(\mathrm{V} 163110 \mathrm{~A}$, Table 2). Tiny Pl crystals are also sparsely present in other experimental runs (as recognized by image analysis; Table 2) but their very small dimension prevents to collect reliable analysis. The small number of analyzed crystals, along with the relatively re-stricted stability field, preclude identification of any systematic compo-sitional variation with experimental parameters. 


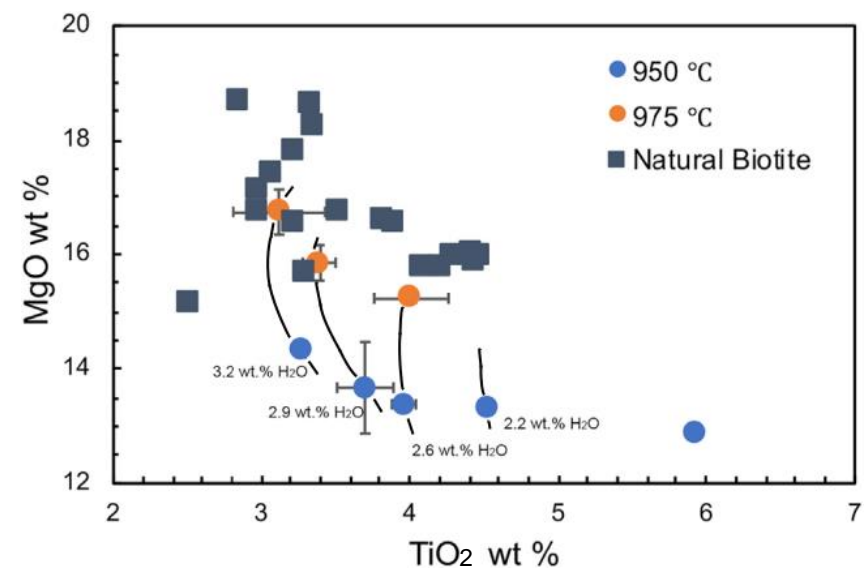

Fig. 5. Natural and experimental compositions of mica. For experimental compositions, the relation with the $\mathrm{H}_{2} \mathrm{O}_{\text {melt }}$ is also shown.

\subsubsection{Glass}

The compositional variation of experimental glass (Table S12) de-fines a single coherent trend that broadly reproduces natural whole rock and glasses (residual glass and MI; Fig. 6), the latter mostly falling near the cold end of the experimental T-range investigated.

The variations of some representative oxides with temperature and water content in the fluid are shown in Figs. 7 and 8, respectively. As temperature decreases, $\mathrm{Al}_{2} \mathrm{O}_{3}, \mathrm{~K}_{2} \mathrm{O}$ increase, while $\mathrm{MgO}, \mathrm{CaO}$ and $\mathrm{FeO}$ decrease (although not always monotonically, as in the case of FeO; Fig. 8), reflecting the onset of Bt crystallization and the increasing role of $\mathrm{Cpx}$ with decreasing $\mathrm{T}$ in the precipitating assemblage (Table 2; Fig. 3)
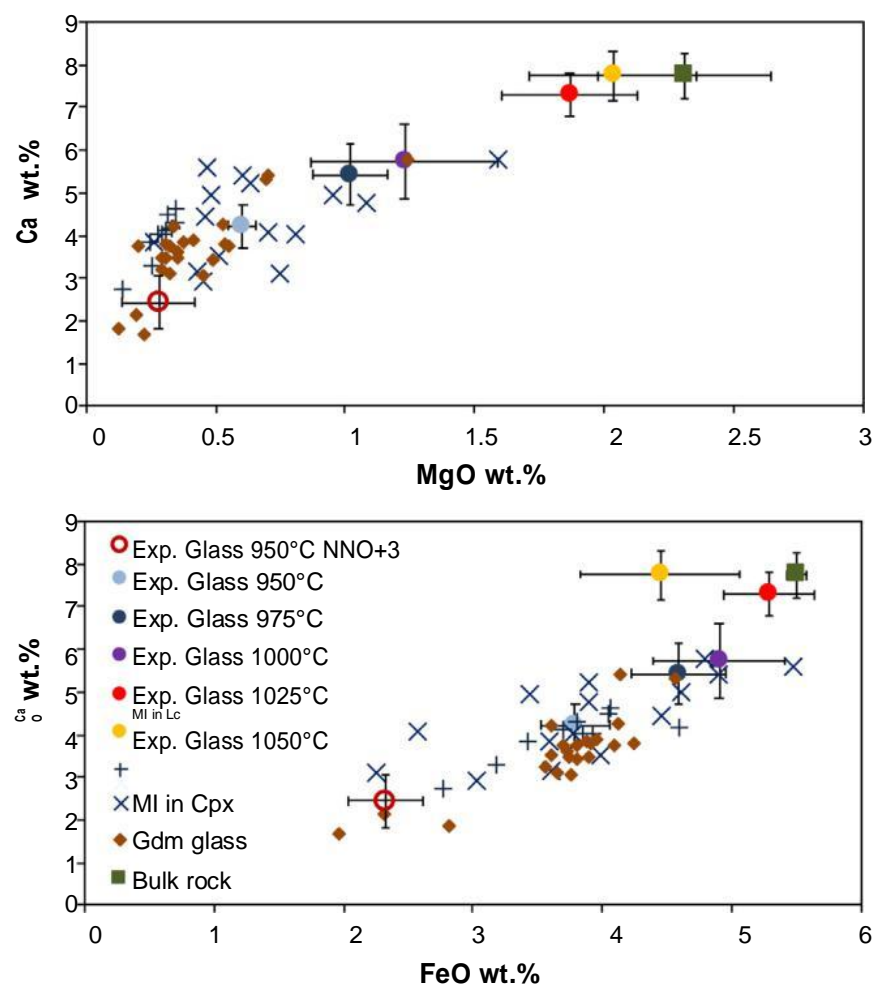

Fig. 6. Covariation of $\mathrm{CaO}, \mathrm{MgO}$ and $\mathrm{FeO}$ contents in experimental and natural glasses (melt inclusions and groundmass). Bulk rock composition of the starting material is also shown for comparison.
At each temperature, the variation of $\mathrm{XH}_{2} \mathrm{O}$ fluid in the charge pro-duces a change in oxide concentrations as well (Fig. 8), albeit of lower magnitude relative to that induced by temperature (Fig. 7). Both $\mathrm{MgO}$ and $\mathrm{CaO}$ concentrations, in particular, display a regular decrease as $\mathrm{XH}_{2} \mathrm{Ofluid}$ (or $\mathrm{H}_{2} \mathrm{O}_{\text {melt }}$ ) decreases at fixed temperature, showing that the general increase of crystal content at lower water content in the melt involves massive Cpx crystallization (especially at low tempera-ture; Table 2 and Fig. 8). Conversely, oxides like $\mathrm{K}_{2} \mathrm{O}$ (or also $\mathrm{FeO}$ ) show more complex trends, as they may either increase or decrease with the progressive change of $\mathrm{XH}_{2} \mathrm{O}$ fluid (Fig. 7), depending on whether leucite or biotite, or both, crystallize.

As stated above, phase relations (Fig. 3) and mass balance calcula-tions of phase proportions (Table 2), indicate that Cpx represents the main phase controlling the general compositional variations of the melt in the investigated $\mathrm{T}-\mathrm{H}_{2} \mathrm{O}$ range. In particular, our data show a first order dependence on $\mathrm{T}$ and a minor dependence on $\mathrm{H}_{2} \mathrm{O}_{\text {melt }}$ (and hence on $\mathrm{XH}_{2} \mathrm{O}$ fluid; Fig. 8).

As for $\mathrm{Cpx}$, the strong correlations of some oxides like $\mathrm{MgO}$ or $\mathrm{CaO}$ with $\mathrm{T}$ allow us to draw two simple geothermometric empirical rela-tionships, mainly based on a linear dependence of oxide content with $\mathrm{T}$, at each given $\mathrm{H}_{2} \mathrm{O}_{\text {melt }}$ A multiple linear fitting analysis is used to de-fine the correlation between oxide $(\mathrm{CaO}$ or $\mathrm{MgO}$ wt $\%), \mathrm{H}_{2} \mathrm{O}_{\text {melt }}(\mathrm{wt} \%)$ and $\mathrm{T}\left({ }^{\circ} \mathrm{C}\right)$. We can write the general fitting relationships as:

T ठ ${ }^{\circ} \mathrm{CP} 1 / 4$ aox ठwt\%oxP p box wt $\% \mathrm{H}_{2} \mathrm{O}$ melt $p$ cox

Parameters calculated for $\mathrm{MgO}(\mathrm{a} \mathrm{MgO}=53.8 \pm 3.1 ; \mathrm{b} \mathrm{MgO}=-15.1 \pm 3.3$; $\mathrm{cMgO}=961.2 \pm 8.3$ ) give a fit with an $\mathrm{R}^{2}=0.93$ and a Standard Error $=9.9$, while those for $\mathrm{CaO}(\mathrm{aCaO}=24.2 \pm 1.3 ; \mathrm{b} \mathrm{CaO}=-18.1 \pm 3.0 ; \mathrm{c} \mathrm{CaO}=895.7 \pm$ 8.9), with an $\mathrm{R}^{2}=0.94$ and a Standard Error $=8.9$.

When compared with the values of $\mathrm{T}$ estimated using the empirical thermometric relationship of Cioni et al. (1999), the here proposed CaO-inglass thermometer gives generally lower and more accurate values (Fig. SM1 in Supplementary Material), possibly reflecting the quite im-portant dependence on the dissolved water content which was not con-sidered by Cioni et al. (1999).

\subsection{High $\mathrm{fO}_{2}$ experiments}

The run product compositions of the charges run at $950{ }^{\circ} \mathrm{C}$ and var-iable $\mathrm{XH}_{2} \mathrm{O}$ fluid (from 1 to 0.4 ) under highly oxidizing $\mathrm{fO}_{2}$ conditions $(\mathrm{NNO}+3$ ) are given in Table S13. These charges have the highest crystal content (always around $30 \mathrm{wt} \%$, from mass balance calculations), as borne out by the highest $\mathrm{SiO}_{2}$ content of residual glasses, with an aver-age value of $57.8 \pm 0.8 \mathrm{wt} \%$, significantly above the average composition of experimental glasses obtained at the same temperature at $\mathrm{NNO}+1(54.5 \pm 0.3 \mathrm{wt} \%)$. Similar to $\mathrm{SiO}_{2}$, also other oxides like $\mathrm{CaO}, \mathrm{MgO}$ or $\mathrm{FeO}$ clearly show a more evolved composition for these glasses (Fig. 6). This increase in $\mathrm{SiO}_{2}$ merely results from the profuse crystalliza-tion of iron oxides, and in the generally more extended crystallization occurring under these conditions. Similar to other experiments, the main mineral paragenesis is formed by $\mathrm{Cpx}+\mathrm{Bt}+$ Oxides. An intermediate plagioclase $(A n 47-52)$ is present in very low amount at this low temperature. Despite the highest crystal content, the composition of the main mineral phases is however always Mg-richer (Table S13) than those formed at lower $\mathrm{fO}_{2}$ conditions ( $\mathrm{NNO}+1$ ), as anticipated from the role of $\mathrm{fO}_{2}$ on FellMg silicate minerals (i.e., Scaillet and Evans, 1999).

\section{Discussion}

\subsection{Phase stability and composition}

The experimental results reported above were acquired with stan-dard laboratory procedures which have proven successful for 

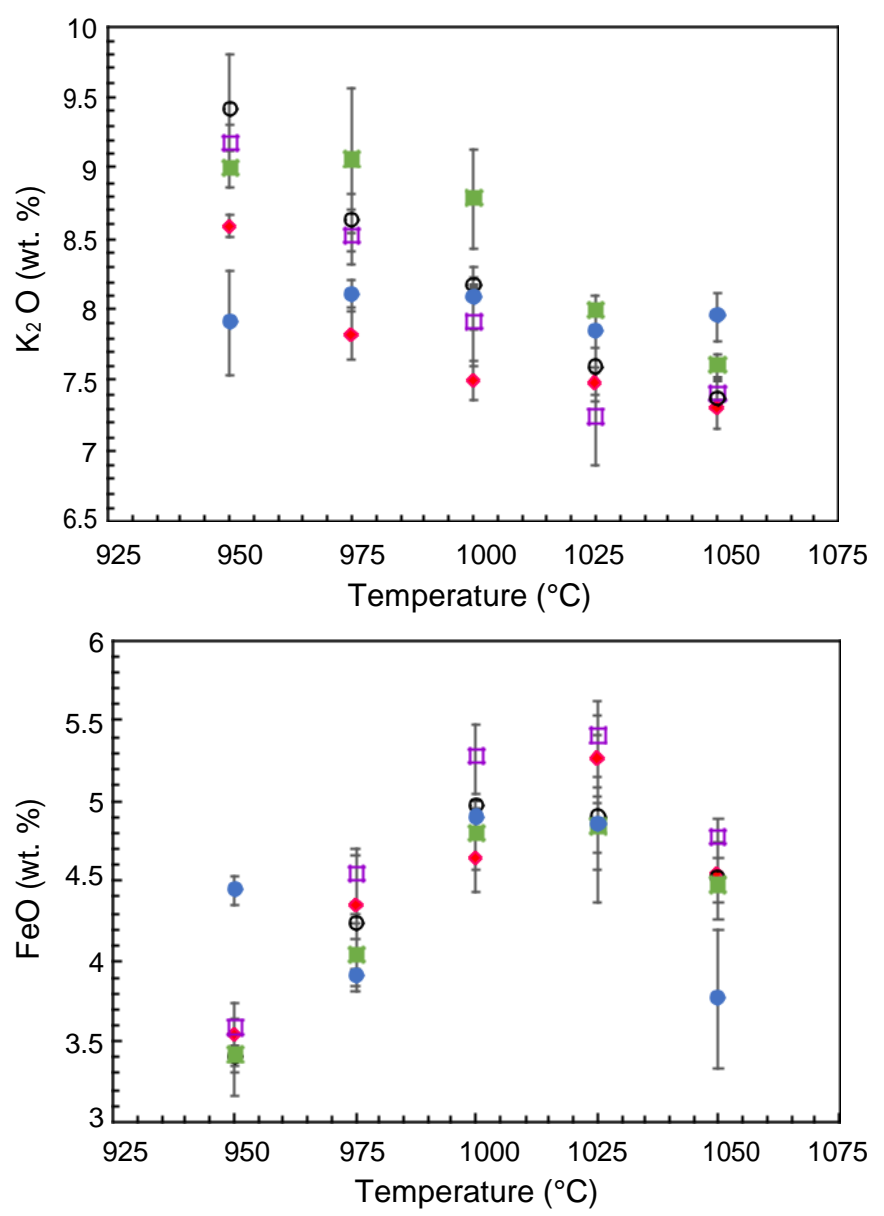

- $\mathrm{XH}_{2} \mathrm{Off}_{1} \square \mathrm{XH}_{2} \mathrm{Of}_{\mathrm{f}} 0.9 \circ \mathrm{XH}_{2} \mathrm{Off}_{0.8} \square \mathrm{XH}_{2} \mathrm{Of}_{\mathrm{f}} 0.7 \bullet \mathrm{XH}_{2} \mathrm{O}_{\mathrm{f}} 0.4$

Fig. 7. Variation of $\mathrm{K} 2 \mathrm{O}$ and $\mathrm{FeO}$ contents in experimental glass with temperature, for the different initial $\mathrm{XH}_{2} \mathrm{O}$ fluid.

establishing phase equilibria in a variety of magma compositions (e.g., Martel et al., 1998; Scaillet and Evans, 1999; Di Carlo et al., 2006; Cadoux et al., 2014; Andújar et al., 2015), including Vesuvius (Scaillet et al., 2008; Pichavant et al., 2014). All those studies have demonstrated that the use of dry glass as starting material favors crystal-liquid equilib-ria within reasonable laboratory time scales (hours to days, depending on temperature), enabling one in turn to assess to which extent crystal-liquid equilibria were also attained in the reservoir prior to erup-tion. The starting composition for our experiments is a tephritic phonolite, with a composition mid-way between the phonolite compositions used by Scaillet et al. (2008) and the mafic tephrite investigated by Pichavant et al. (2014), representative of the first erupted products. The regular compositional trends with experimental parameters, the compositional homogeneity and spatial distribution of the different

mineral phases in any given charge, all suggest that bulk equilibrium was closely approached in our experiments. The value of $\mathrm{K}^{\mathrm{Fe} / \mathrm{Mg}}$ De-

tween $\mathrm{Cpx}$ and melt varies in the different experimental charges be-tween 0.18 and 0.28 , within the range suggested by Putirka (2008) for pyroxene-melt equilibrium. Finally, the overall good match between phase assemblages in run products and in natural 1631 tephra, attests that the experimental conditions were successful in reproducing the main petrological attributes, encompassing the $\mathrm{P}-\mathrm{T}-\mathrm{H}_{2} \mathrm{O}$ conditions likely to have prevailed in the 1631 reservoir, at least in its top portion.

In general terms, the phase relationships are similar to those established for the more primitive Vesuvius magma by Pichavant et al. (2014), the main difference being the overall down temperature shift of liquidus curves, reflecting the less mafic character of the 1631
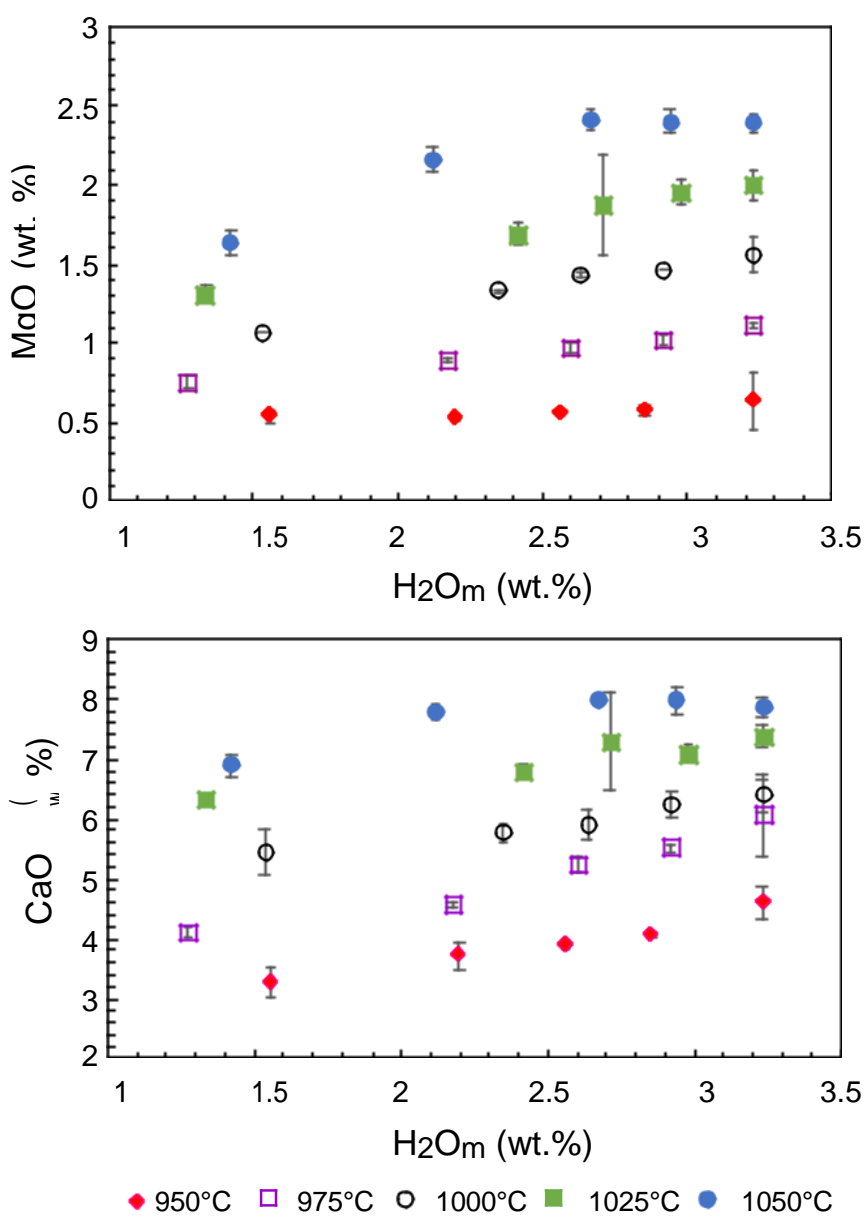

Fig. 8. Glass compositional variations of $\mathrm{CaO}$ and $\mathrm{MgO}$ in experimental glass as a function of the $\mathrm{H} 2 \mathrm{O}_{\text {melt }}$ in the different experimental charges.

magma used in our study. For instance, at $\mathrm{H}_{2} \mathrm{O}$-saturation, biotite/phlog-opite is stable over $1050^{\circ} \mathrm{C}$ in the more mafic composition, while it re-acts out above $1000{ }^{\circ} \mathrm{C}$ in our composition. Similarly, Cpx liquidus is located over $1120{ }^{\circ} \mathrm{C}$ in the more mafic compositions, or about $100{ }^{\circ} \mathrm{C}$ higher than in 1631 rock. Pichavant et al. (2014) did not report a stabil-ity field for Pl, possibly because they investigated only the $\mathrm{H}_{2} \mathrm{O}$-rich por-tion at $200 \mathrm{MPa}$. Conversely, $\mathrm{Pl}$ is stable in our experiments in the water-poor section of the phase diagram, or, up to water saturation, at temper-ature below $950{ }^{\circ} \mathrm{C}$. Comparison with the phase equilibria established on the more evolved potassic Vesuvian phonolites by Scaillet et al. (2008) reveals that the latter also display the same topological arrange-ment for the main phases (Lc, Cpx, Pl), liquidus curves being equally displaced down temperature relative to 1631 composition. The phono-lite compositions display liquidus temperatures ( $\mathrm{Cpx}$ ) around $850-900{ }^{\circ} \mathrm{C}$ at $\mathrm{H}_{2} \mathrm{O}$ saturation, in agreement again with their more felsic character as compared to 1631 composition. The crystal content is strongly related to the initial water content of the melt, with an amount of crystallization higher than $30 \%$ only for the water-poor region of the phase diagram (Fig. 3). As shown by the experiment run at $\mathrm{NNO}+3$, an increase in $\mathrm{fO}_{2}$ shifts the composition of FellMg phases toward higher $\mathrm{MgO}$ contents, also accommodating a larger amount of crystallization respect to less oxidized conditions.

\subsection{Pre-eruptive conditions}

A first inference on pre-eruptive conditions can be done using phase equilibrium arguments alone. The mineralogy of the 1631 rocks is made of $\mathrm{Cpx}, \mathrm{Lc}, \mathrm{Bt}, \mathrm{Pl}$, amounting to $20-30 \mathrm{wt} \%$, though this figure may be 
partly overestimated owing to the fact that not all Lc belongs to pre-eruptive phenocrysts, some of it having possibly grown during ascent, and at least part of the Cpx phenocrysts are xenocrysts/antecrysts. How-ever, simple mass balance calculations between the composition of the starting material (Table 1) and the average composition of MI in pheno-crysts (Table S6) suggest a similar amount of crystallization (around $30 \mathrm{wt} \%$ ) of a Cpx-dominated mineral paragenesis. Crystallization around $100 \mathrm{MPa}$ is suggested by the similarity of 1631 composition and petrology with that of the AD472 Pollena eruption (Scaillet et al., 2008) and by the calculation on $\mathrm{Cl}$ solubility by BalconeBoissard et al. (2016). Accounting for these, the equilibrium mineralogical assemblage is reproduced at temperatures below $975^{\circ} \mathrm{C}$, and for $\mathrm{H}_{2} \mathrm{O}_{\text {melt }}$ lower than about $2.5 \mathrm{wt} \%$. If magma crystallinity and the fact that $\mathrm{Pl}$ is subordinate to Lc are considered, a pre-eruption magma temperature not much lower than $950{ }^{\circ} \mathrm{C}$ is implied, while $\mathrm{H}_{2} \mathrm{O}_{\text {melt }}$ significantly lower than 2 wt $\%$ appears unlikely. In many Vesuvius eruptions, Lc is present in large proportions as microphenocrysts possibly formed, according to the very high growth rate typical of these crystals (Shea et al., 2009), by syn-eruptive, decompressiondriven crystallization. For this reason, if most of the Lc microphenocrysts crystallized syn-eruptively, pre-eruptive temperatures lower than $950{ }^{\circ} \mathrm{C}$ are also possible, which would imply $\mathrm{H}_{2} \mathrm{O}_{\text {melt }}>2.3 \mathrm{wt} \%$. The occurrence of rare Amph crystals, only present in the analyzed natural sample as an inclusion in a Lc phe-nocryst, suggests that Amph grew first, followed by Lc. These textural relationships may correspond to an early stage of magma evolution, in the temperature range $1000-1025{ }^{\circ} \mathrm{C}$, during which $\mathrm{H}_{2} \mathrm{O}_{\text {melt }}$ was $>2$ wt $\%$ (Fig. 3), so as to stabilize this sequence of crystallization.

More information can be gained by combining the natural phase compositions with the experimental observations detailed above. Owing to its greater abundance, $\mathrm{Cpx}$ can give important clues on pre-eruptive conditions of the 1631 magma. Both $\mathrm{Al}_{2} \mathrm{O}_{3}$ and $\mathrm{TiO}_{2}$ exhibit a strong negative dependence with temperature (Fig. 1; Table S1). The smaller Cpx, or the re-equilibrated rims of larger crystals, have $\mathrm{Al}_{2} \mathrm{O}_{3}$ and $\mathrm{TiO}_{2}$ contents indicating temperatures of crystallization below $1000{ }^{\circ} \mathrm{C}$, possibly around $950{ }^{\circ} \mathrm{C}$ and water-rich conditions, while the Ti- and $\mathrm{Al}$-poor $\mathrm{Cpx}$ point to temperatures above 1000 ${ }^{\circ} \mathrm{C}$. Similarly, the Mg-rich $(\mathrm{Mg} /(\mathrm{Mg}+\mathrm{Fe})=0.8) \mathrm{Cpx}$, if issued from a 1631like magma, records temperatures higher than $1000{ }^{\circ} \mathrm{C}$, generally around 1050 ${ }^{\circ} \mathrm{C}$ (Figs. 1a, 4). The Mg-poor rim of $\mathrm{Cpx}$ has $\mathrm{Mg} /\left(\mathrm{Mg}+\mathrm{Fe}_{\mathrm{T}}\right)=0.5$ (Fig. 1c), pointing to pre-eruptive temperatures in the range $900-950{ }^{\circ} \mathrm{C}$. However, some natural $\mathrm{Cpx}$ show even lower $\mathrm{Mg} /(\mathrm{Mg}+\mathrm{Fe}$ ), down to 0.3 (Fig. 1c), suggesting excursion of the system to temperatures significantly lower than 950 ${ }^{\circ} \mathrm{C}$. Such Mg-poor crystals may come from the outer shell of the reservoir, being re-incorporated into the warmer interior by convective processes, thereafter serving as nucleation sites for new, Mg-richer, crystals. Excluding the cold outliers, temperature fluctuations recorded by $\mathrm{Cpx}$ lie in the range $900-$ $1000{ }^{\circ} \mathrm{C}$ (Fig. 4). Bt composition changes with temperature and $\mathrm{XH}_{2} \mathrm{O}$ fluid, the $\mathrm{Mg} /(\mathrm{Mg}+\mathrm{Fe})$ of natural biotite falling in the range of those experi-mentally produced. Variation in $\mathrm{XH}_{2} \mathrm{O}$ fluid in particular affects $\mathrm{TiO}_{2}$ con-tent (Fig. 5): a $\mathrm{TiO}_{2}$ content of about $4.5 \mathrm{wt} \%$, as observed in the rim of the largest fresh crystal analyzed (Table $\mathrm{S} 4$ ), indicates a $\mathrm{XH}_{2} \mathrm{O}$ fluid of about 0.7 , corresponding to a $\mathrm{H}_{2} \mathrm{O}_{\text {melt }}$ of about 2.2-2.6 wt\% (at $100 \mathrm{MPa}$; Fig. 5). The Mg-rich Bt has a $\mathrm{TiO}_{2}$ of about $3 \mathrm{wt} \%$ correspond-ing to conditions close to $\mathrm{H}_{2} \mathrm{O}$ saturation, but those Mg-rich crystals may also come from more primitive magmas or from crystallization under highly oxidizing conditions. Lc composition of phenocrysts is reasonably approached by the experimental one, but slightly more $\mathrm{Na}_{2} \mathrm{O}$ rich than the experimental $\mathrm{Lc}\left(0.8-0.9\right.$ vs. $0.6 \mathrm{wt} \% \mathrm{Na}_{2} \mathrm{O}$, respectively; Tables S2, S9). The small-sized Lc consistently has higher $\mathrm{Na}_{2} \mathrm{O}$ contents, which are not reproduced in our experiments, suggesting that those crystals grew during decompression and not in the reservoir, in agreement with textural evidence (Cioni et al., 1995; Shea et al., 2009). The sole Amph analyzed in the rocks is similar to that of the experiments, but the scarce occurrence of this mineral in both pumice and run products is not of a great help for estimating pre-eruptive conditions. In contrast, as for $\mathrm{Cpx}$, the composition of glass inclusions in both $\mathrm{Cpx}$ and Lc can be used to infer $\mathrm{T}-\mathrm{XH}_{2} \mathrm{O}$ fluid (or $\mathrm{H}_{2} \mathrm{O}_{\text {melt }}$ ) values. Using our $\mathrm{MgO}$ and $\mathrm{CaO}-$ in glass thermometric relations derived above, temperatures of around $950-960{ }^{\circ} \mathrm{C}$ for the $\mathrm{CaO}$ equation and $940-960^{\circ} \mathrm{C}$ for the $\mathrm{MgO}$ one are calculated if $\mathrm{XH}_{2}$ Ofluid is set to 0.7 (corresponding to an $\mathrm{H}_{2} \mathrm{O}_{\text {melt }}$ of about $2.3 \mathrm{wt} \%$, Fig. 3), being in general agreement with the values in-ferred from Cpx thermometry.

Finally, the compositional range of the glass from experiments at 950 and $975{ }^{\circ} \mathrm{C}$ is similar to that of the natural rock, although some dis-crepancies are observed. In detail, natural glass differs from the experi-mental one for some oxides, in particular $\mathrm{K}_{2} \mathrm{O}$ (Table S7). This is in large part related to the massive final crystallization of leucite, which is very abundant in the groundmass of natural products, whereas it is present in smaller quantities in the experimental run products. As expected, leu-cite stability field increases markedly at low pressure (e.g., Taylor and MacKenzie, 1975; Scaillet et al., 2008), while Shea et al. (2009) observed an important increase of the nucleation rate (in phonolite melts) for $\mathrm{P}<30 \mathrm{MPa}$ at $\mathrm{T}$ around $850{ }^{\circ} \mathrm{C}$, conditions similar to those possibly en-countered during the final magma ascent. This therefore suggests that a significant part of the leucite presents in the groundmass of natural products, and which contributes to strongly change the composition of the residual glass by impoverishing it in $\mathrm{K}_{2} \mathrm{O}$, grew syn-eruptively, during the rise of magma to the surface.

Overall there is a good agreement between phase equilibrium con-straints and mineral compositions: assuming a pre-eruptive pressure around $100 \mathrm{MPa}$ (Scaillet et al., 2008), the combination of the two sets of data yields a preeruptive temperature at $950{ }^{\circ} \mathrm{C} \pm 30{ }^{\circ} \mathrm{C}$, with $\mathrm{H}_{2} \mathrm{O}_{\text {melt }}=2.3 \pm 0.3 \mathrm{wt} \%$. The temperature is in agreement with the thermometric relationships on pyroxene and with the observed compo-sition of natural biotite and glass (Fig. 5). Suggested conditions also re-produce the phenocryst abundance observed in the first erupted pumices (20-30 wt $\%$ ). The fact that the experiments performed at around $\mathrm{NNO}+1$ reproduce the compositions of FellMg bearing phases suggests that similar redox conditions were prevailing in the reservoir, as concluded by Pichavant et al. (2014) for primitive magma batches feeding the reservoir.

\subsection{Volcanological implications}

The experimental study on phase equilibria allowed us to define the preeruptive conditions of the products of the Vesuvius eruption of 1631 , in terms of pressure, temperature and magma water contents. The pre-eruptive conditions are essentially similar to those inferred for that eruption, on petrological grounds only and by similarity with the experimental results obtained on the products of the AD472 Pollena eruption of Vesuvius, by Scaillet et al. (2008). In detail, the comparison with pre-eruptive conditions inferred for the AD472 Pollena event indi-cates that the average minimum temperature of the extruded 1631 magma was 100 to $150{ }^{\circ} \mathrm{C}$ hotter than that for Pollena. This is direct ev-idence for either an increased mass flux of mafic magmas entering the system or for a smaller residence time between eruptive events, or both, perhaps favoured by the shallower storage conditions relative to the pre-Pompeii state, an evolution already inferred on petrological and geochemical grounds (Santacroce et al., 2008).

Our results thus confirm that, following the AD79 Pompeii eruption, magma storage conditions at Vesuvius significantly changed, in particu-lar with the activation of a shallower reservoir where magma could stall at low pressure before being erupted and by an increase in the temper-ature of the apical portion of the feeding reservoir. This change in the plumbing system also coincided with an important increase in the alkali content of the magma involved in the AD79 activity (Santacroce et al., 2008). Conditions of shallower magma storage possibly persisted dur-ing the last 2000 years of activity, as also suggested by melt inclusion data on the products of the last Vesuvius eruption in 1944 (Marianelli et al., 1999). It is worth stressing that crystallization of the parental magma feeding this shallower reservoir also occurred at depths greater 
than 8-10 km (> $200 \mathrm{MPa}$; Marianelli et al., 2005; Pichavant et al., 2014), which altogether suggests the persistence of magma stalling around this depth throughout the entire activity of Somma-Vesuvius.

Experimental data on the 1631 products also suggest that magma, stored at around $100 \mathrm{MPa}$, was water-undersaturated. We stress here that pressure conditions significantly higher than $100 \mathrm{MPa}$ seem pre-cluded, in view of the diminished stability of Leucite at high pressures (Scaillet et al., 2008). All these facts can be crucial to interpretation of monitoring signals associated to magma unrest; in fact, the conditions of $\mathrm{H}_{2} \mathrm{O}$ undersaturation imply that if the reservoir was fluid-saturated (as suggested by the interpretation of precursory signals to the erup-tion; Bertagnini et al., 2006; Principe and Marini, 2008), then the coexisting fluid had a significant amount of $\mathrm{CO}_{2}$, with $\mathrm{XCO}_{2}$ fluid in the range $0.4-0.5$ (Fig. 3). This is also consistent with many observations concerning carbonate assimilation by Vesuvius magmas (e.g., Iacono-Marziano et al., 2009; Stabile and Carroll, 2020).

Hence, any fluid phase escaping a 1631-like reservoir should be marked by $\mathrm{CO}_{2}$-rich gases emanating at the surface (compared to the case of Pollena AD472, with a reservoir capped by a cold and water-rich phonolitic magma with $\mathrm{XCO}_{2}$ fluid $<0.1$, Scaillet et al., 2008). The processes of $\mathrm{CO}_{2}$ flushing, possibly supplied by early crystallization of mafic magma at depth (Marianelli et al., 2005; Pichavant et al., 2014) or thermal/metasomatic decarbonation of the basement (Iacono-Marziano et al., 2009; Dallai et al., 2011), could help in sustaining a $\mathrm{CO}_{2}$-rich fluid phase at these shallow depths.

\section{Conclusions}

The described phase equilibria had no particular problem in replicat-ing the petrographical features of the studied rock, including mineral phase and residual glass compositions. The logical conclusion is that near-equilibrium conditions, in particular at the crystal rim-melt inter-face, were prevailing in the top part of the tapped reservoir prior to eruption. This observation should be integrated in models aimed at deciphering the triggering mechanism of the 1631 eruption. Pre-eruptive conditions for 1631 magma can be fixed at $P=100$ MPa, (mainly based on previous studies; Scaillet et al., 2008; Balcone-Boissard et al., 2016), temperature of $950 \pm 30^{\circ}$ and $\mathrm{H}_{2} \mathrm{O}_{\text {melt }}=2.3 \pm 0.3 \mathrm{wt} \%$, corresponding to an $\mathrm{XH}_{2} \mathrm{O}$ fluid-final around $0.5-0.6$, for an oxy-gen fugacity around $\mathrm{NNO}+1$. These conditions suggest the presence in the shallow reservoir of a $\mathrm{CO}_{2}$-rich fluid phase, possibly fuelled by $\mathrm{CO}_{2}$-rich fluids emanating from magma crystallization and/or interac-tion with the carbonate basement at deeper levels of the plumbing sys-tem. Such a two-level system functioning should be considered in the interpretation of geochemical monitoring data in case of a next reactiva-tion of the volcano.

The evidence of magma storage at $3-4 \mathrm{~km}$ depth agrees with what is already observed for other eruptions of the post-AD79 period, confirming the shallowing of magma reservoirs in the recent evolution of the Somma-Vesuvius volcanic complex.

Supplementary data to this article can be found online at https://doi. org/10.1016/j.jvolgeores.2020.107076.

\section{CRediT authorship contribution statement}

IB: experimental and analytical work, data analysis and tables com-pilation, writing and reviewing. RC: project planning and supervision, data analysis, preparation of iconographic material, writing and reviewing. BS: project planning, supervision of experimental work, data analysis, writing and reviewing.

\section{Declaration of competing interest}

The authors declare that they have no known competing financial interests or personal relationships that could have appeared to influ-ence the work reported in this paper.

\section{Acknowledgements}

We are deeply indebted to Editor James Gardner and the two anon-ymous referees for their critical assessment of the work and the very ac-curate and constructive reviews that improved considerably the paper. This study forms the first part of the PhD work of the first author on the Vesuvius-Campi Flegrei volcanic district, carried out within the frame-work of Italy-France grant awarded by the Italian-French University of Turin (grant C3-92/2016). The laboratory activities and travels between Firenze and Orléans have been funded by projects Labex VOLTAIRE (France, LABX-100-01), Equipex PLANEX (France, ANR-11-EQPX-0036), and EVE FP7 (ERC, DG ECHO 826292).

\section{References}

Andújar, J., Scaillet, B., Pichavant, M., Druitt, T.H., 2015. Differentiation conditions of a basaltic magma from Santorini, and its bearing on the production of andesite in arc set-tings. J. Petrol. 56 (4), 765-794.

Auger, E., Gasparini, P., Virieux, J., Zollo, A., 2001. Seismic evidence of an extended mag-matic sill under Mt. Vesuvius. Science 294 (5546), 1510-1512.

Balcone-Boissard, H., Boudon, G., Cioni, R., Webster, J.D., Zdanowicz, G., Orsi, G., Civetta, L., 2016. Chlorine as a geobarometer for alkaline magmas: evidence from a systematic study of the eruptions of Mount Somma-Vesuvius. Sci. Rep. 6, 21726.

Barberi, F., Macedonio, G., Pareschi, M.T., Santacroce, R., 1990. Mapping the tephra fallout risk: an example from Vesuvius, Italy. Nature 344 (6262), 142-144.

Behrens, H., Misiti, V., Freda, C., Vetere, F., Botcharnikov, R.E., Scarlato, P., 2009. Solubility of $\mathrm{H} 2 \mathrm{O}$ and $\mathrm{CO} 2$ in ultrapotassic melts at 1200 and $1250 \mathrm{C}$ and pressure from 50 to $500 \mathrm{MPa}$. Am. Mineral. 94 (1), 105-120.

Bertagnini, A., Cioni, R., Guidoboni, E., Rosi, M., Neri, A., Boschi, E., 2006. Eruption early warning at Vesuvius: the AD 1631 lesson. Geophys. Res. Lett. 33 (18).

Blundy, J., Cashman, K.V., 2008. Petrologic reconstruction of magmatic system variables and processes. Rev. Mineral. Geochem. 69 (1), 179-239.

Cadoux, A., Scaillet, B., Druitt, T.H., Deloule, E., 2014. Magma storage conditions of large Plinian eruptions of Santorini Volcano (Greece). J. Petrol. 55 (6), 1129-1171.

Cashman, K.V., 2004. Volatile controls on magma ascent and eruption. GMS, 150, 109-124. In: Sparks, R.S.J., Hawkesworth, C.J. (Eds.), Geophys. Monogr. Ser. vol. 150. AGU, Washington, D. C, pp. 109-124.

Cioni, R., 2000. Volatile content and degassing processes in the AD 79 magma chamber at Vesuvius (Italy). Contrib. Mineral. Petrol. 140 (1), 40-54.

Cioni, R., Civetta, L., Marianelli, P., Metrich, N., Santacroce, R., Sbrana, A., 1995. Compositional layering and syn-eruptive mixing of a periodically refilled shallow magma chamber: the AD 79 Plinian eruption of Vesuvius. J. Petrol. 36 (3), 739-776.

Cioni, R., Marianelli, P., Santacroce, R., 1998. Thermal and compositional evolution of the shallow magma chambers of Vesuvius: evidence from pyroxene phenocrysts and melt inclusions. J. Geophys. Res. Solid Earth 103 (B8), 18277-18294.

Cioni, R., Marianelli, P., Santacroce, R., 1999. Temperature of Vesuvius magmas. Geology 27 (5), 443-446.

Cioni, R., Longo, A., Macedonio, G., Santacroce, R., Sbrana, A., Sulpizio, R., Andronico, D., 2003. Assessing pyroclastic fall hazard through field data and numerical simulations: example from Vesuvius. J. Geophys. Res. Solid Earth 108 (B2)

Cioni, R., Bertagnini, A., Santacroce, R., Andronico, D., 2008. Explosive activity and eruption scenarios at Somma-Vesuvius (Italy): towards a new classification scheme. J. Volcanol. Geotherm. Res. 178 (3), 331-346.

Dallai, L., Cioni, R., Boschi, C., D’Oriano, C., 2011. Carbonate-derived CO2 purging magma at depth: influence on the eruptive activity of Somma-Vesuvius, Italy. Earth Planet. Sci. Lett. 310 (1-2), 84-95.

Di Carlo, I., Pichavant, M., Rotolo, S.G., Scaillet, B., 2006. Experimental crystallization of a high-K arc basalt: the golden pumice, Stromboli volcano (Italy). J. Petrol. 47, 1317-1343.

Di Matteo, V., Carroll, M.R., Behrens, H., Vetere, F., Brooker, R.A., 2004. Water solubility in trachytic melts. Chem. Geol. 213, 187-196.

Fulignati, P., Marianelli, P., 2007. Tracing volatile exsolution within the 472 AD "Pollena" magma chamber of Vesuvius (Italy) from melt inclusion investigation. J. Volcanol. Geotherm. Res. 161 (4), 289-302.

Holloway, J.R., 1987. Igneous fluids. In thermodynamic modeling of geological materials: minerals fluids and melts. Rev. Mineral. 17, 211-233.

Iacono-Marziano, G., Gaillard, F., Scaillet, B., Pichavant, M., Chiodini, G., 2009. Role of nonmantle $\mathrm{CO} 2$ in the dynamics of volcano degassing: the Mount Vesuvius example. Ge-ology 37 (4), 319-322.

Marianelli, P., Métrich, N., Sbrana, A., 1999. Shallow and deep reservoirs involved in magma supply of the 1944 eruption of Vesuvius. Bull. Volcanol. 61 (1-2), 48-63.

Marianelli, P., Sbrana, A., Metrich, N., Cecchetti, A., 2005. The deep feeding system of Vesuvius involved in recent violent strombolian eruptions. Geophys. Res. Lett. 32 (2).

Martel, C., Pichavant, M., Bourdier, J.L., Traineau, H., Holtz, F., Scaillet, B., 1998. Magma storage conditions and control of eruption regime in silicic volcanoes: experimental evidence from Mt. Pelée. Earth Planet. Sci. Lett. 156 (1-2), 89-99.

Marziano, G.I., Schmidt, B.C., Dolfi, D., 2007. Equilibrium and disequilibrium degassing of a phonolitic melt (Vesuvius AD 79 "white pumice") simulated by decompression ex-periments. J. Volcanol. Geotherm. Res. 161 (3), 151-164.

Morimoto, N., 1988. Nomenclature of pyroxenes. Mineral. Petrol. 39 (1), 55-76.

Oppenheimer, C., Fischer, T.P., Scaillet, B., 2014. Volcanic Degassing: Process and Impact. Treatise on Geochemistry. Second edition. vol. 4. Elsevier, pp. 111-179. 
Pichavant, M., Scaillet, B., Pommier, A., Iacono-Marziano, G., Cioni, R., 2014. Nature and evolution of primitive Vesuvius magmas: an experimental study. J. Petrol. 55 (11), 22812310

Putirka, K.D., 2008. Thermometers and barometers for volcanic systems. Rev. Mineral. Geochem. 69 (1), 61-120.

Pyle, D.M., 2015. Sizes of volcanic eruptions. In: Sigurdsson, H., Houghton, B., McNutt, S., Rymer, H., Stix, J. (Eds.), The Encyclopedia of Volcanoes. Academic Press, pp. 257-264.

Rolandi, G., Barrella, A.M., Borrelli, A., 1993. The 1631 eruption of Vesuvius. J. Volcanol. Geotherm. Res. 58 (1-4), 183-201.

Rosi, M., Principe, C., Vecci, R., 1993. The 1631 Vesuvius eruption. A reconstruction based on historical and stratigraphical data. J. Volcanol. Geotherm. Res. 58 (1), 151-182.

Rutherford, M.J., 2008. Magma ascent rates. Rev. Mineral. Geochem. 69 (1), 241-271.

Santacroce, R., Cioni, R., Marianelli, P., Sbrana, A., Sulpizio, R., Zanchetta, G., Donahue, D.J., Joron, J.L., 2008. Age and whole rock-glass compositions of proximal pyroclastics from the major explosive eruptions of Somma-Vesuvius: a review as a tool for distal tephrostratigraphy. J. Volcanol. Geotherm. Res. 177 (1), 1-18.

Sbrana, A., Cioni, R., Marianelli, P., Sulpizio, R., Andronico, D., Pasquini, G., 2020. Volcanic evolution of the Somma-Vesuvius Complex (Italy). J. Maps 16 (2), 137-147.

Scaillet, B., Evans, B.W., 1999. The 15 June 1991 eruption of Mount Pinatubo. I. Phase equilibria and pre-eruption $\mathrm{P}-\mathrm{T}-\mathrm{fO}_{2}-\mathrm{fH}_{2} \mathrm{O}$ conditions of the dacite magma. J. Petrol. 40 (3), 381-411.

Scaillet, B., Pichavant, M., Roux, J., Humbert, G., Lefèvre, A., 1992. Improvements of the Shaw membrane technique for measurement and control of $\mathrm{f} \mathrm{H} 2$ at high tempera-tures and pressures. Am. Mineral. 77 (5-6), 647-655.
Scaillet, B., Pichavant, M., Cioni, R., 2008. Upward migration of Vesuvius magma chamber over the past 20,000 years. Nature 455, 216-219.

Scarpa, R., Tronca, F., Bianco, F., Del Pezzo, E., 2002. High resolution velocity structure beneath Mount Vesuvius from seismic array data. Geophys. Res. Lett. 29 (21) (36-1)

Schneider, C.A., Rasband, W.S., Eliceiri, K.W., 2012. NIH image to ImageJ: 25 years of image analysis. Nat. Methods 9 (7), 671-675.

Shea, T., Larsen, J.F., Gurioli, L., Hammer, J.E., Houghton, B.F., Cioni, R., 2009. Leucite crystals: surviving witnesses of magmatic processes preceding the 79AD eruption at Ve-suvius, Italy. Earth Planet. Sci. Lett. 281 (1-2), 88-98.

Stabile, P., Carroll, M.R., 2020. Petrologic experimental data on Vesuvius and Campi Flegrei magmatism: a review. In: De Vivo, B., Belkin, H.E., Rolandi, G. (Eds.), Vesuvius, Campi Flegrei, and Campanian Volcanism. Elsevier, pp. 323-369.

Stoppa, F., Principe, C., Schiazza, M., Liu, Y., Giosa, P., Crocetti, S., 2017. Magma evolution inside the 1631 Vesuvius magma chamber and eruption triggering. Open Geosci. 9, 24-52.

Stormer Jr., J.C., Nicholls, J., 1978. XLFRAC: a program for the interactive testing of mag-matic differentiation models. Comput. Geosci. 4 (2), 143-159.

Taylor, D., MacKenzie, W.S., 1975. A contribution to the pseudoleucite problem. Contrib. Mineral. Petrol. 49 (4), 321-333. 